Historic, Archive Document

Do not assume content reflects current scientific knowledge, policies, or practices. 

62.37

FEB 


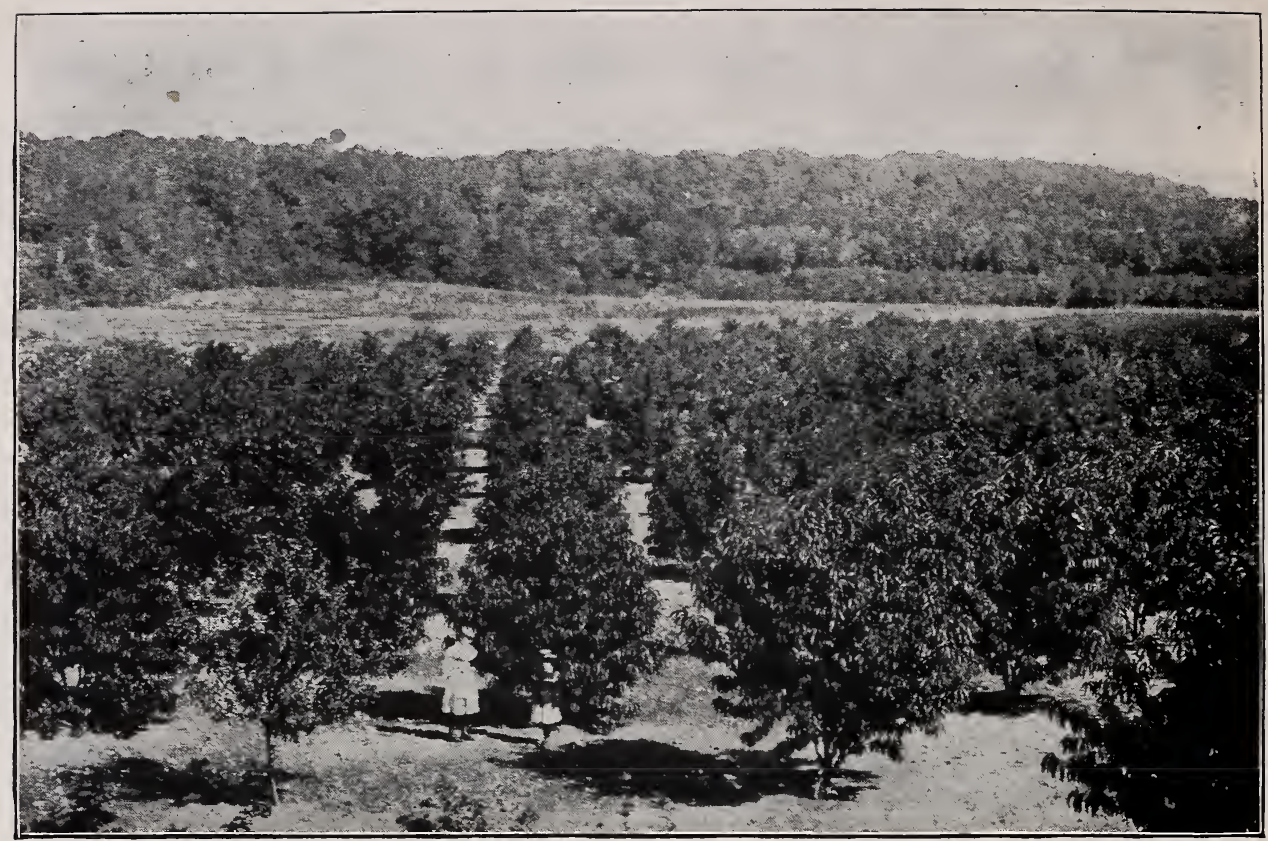

C. W. Ward's Peach Orchard, Queens, L. I., New York, Planted with Our Trees

\section{DOUBLE-CROP PEACH}

\section{Something New in Peaches. Two Crops a Year from each Tree. Our Latest Introduction}

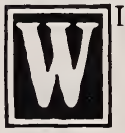

ITH a constant desire to benefit the Peach-growers of the country, we are continually trying to improve the quality of our stock, and to encourage every new introduction of merit. To this end we have been patiently watching the results from a tree growing in our Nursery, which we feel is one of the most distinct novelties ever introduced, and are now ready to offer young trees from the stock.

An official of the Government, F. E. Matthews, of Somerset county, Md., while inspecting our Nurseries, took great pains to investigate the peculiar merits of the Double-Crop Peach, and has the following to say of it:

"In my inspection work the past summer I came across a curiosity in the shape of a seedling Peach tree. This tree has borne twelve consecutive crops (or I should s.ay twenty-four consecutive crops, as it has never failed to bear two crops each year). The first crop is a large white and red fruit of clingstone variety, averaging the size of large Reeves' Favorites, ripening about the middle of August, the next crop ripening the middle to last of September and is much smaller and looks more like a plum. There have always been about as many in number of the smaller as of the larger fruit. The owner of this tree says he has kept this latter crop until Christmas. I think this fruit, especially the first crop, will prove very valuable, as it is one of the largest and most handsome Peaches I have ever seen. The owner says he has never sold the fruit for less than $\$ \mathrm{I}$ per basket, mostly $\$ 1.50$. He is naturally very proud of his tree, which is very large and thrifty, average yearly crop, ten half-bushel baskets. He has never taken much notice of the second crop, regarding it more as a curiosity than of any value, although it is really nice in taste, looking and tasting more like a plum than a Peach."

These words from a practical man are all that is necessary to describe this wonderful Peach. Price, $20 \mathrm{cts}$. each, $\$ 1.75$ for 10, $\$ 15$ for 100. 


\section{R. C. PETERS \& SONS NURSERIES}

IRONSHIRE

发

MARYLAND

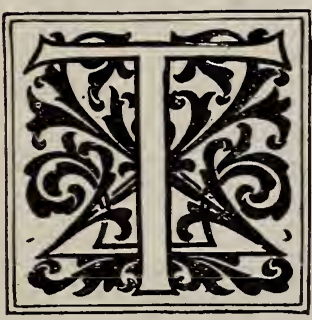

HIS, our latest revised Catalogue of Fruit Trees and other Nursery Stock, is submitted to our friends, our customers, with the consciousness that it is thoroughly up-to-date in all that it contains, and that our stock is, if anything, better than ever before. We use the term "friends" advisedly, for our desire is to so deal with customers as to make them friends, and we are proud of the many commendatory letters we have received from those who have purchased our trees during many years past.

Our nursery experience extends over a generation, as will be seen by reading the history of our nurseries on the following pages; and our operations in growing trees and fruits for many years have ripened our judgment and given us the discriminating experience only obtained with time. It is therefore with the confidence and knowledge born of experience and practice that we present at this time our selection of

\section{FRUIT-BEARING FRUIT TREES}

Surprise may be expressed at the apparent implication that some fruit trees are not fruit-bearing ; yet such is the fact, and the lamentable condition in many places of orchards carefully grown, yet unsuccessful, points more strongly our claim to have growing and for sale only fruit trees that will bear good fruit as soon after planting as nature's economics will permit.

We point with pride and satisfaction to some of the most successful orchards in the United States, which have been planted with our trees, and this, too, when stock less carefully grown has failed to produce good results under the very same conditions which have given profit from our trees.

Our farm, located in a favorable spot in Worcester county, Maryland, includes over five hundred acres, the best portion of which is given to nursery stock. We have extensive experimental orchards, in which we test varieties carefully under commercial conditions and propagate new varieties for our customers.

Giving careful personal attention to the growing, digging and packing of our stock, we are able, with confidence, to recommend it.

Our stock is free from all diseases and insects, and we always supply the certificate of the State Entomologist as to this important fact. Further, we make assurance doubly sure by fumigating with hydrocyanic gas before shipment. Our fumigating plant was used as a model for the showing at the Paris Exposition of 1900.

\section{R. C. PETERS \& SONS}




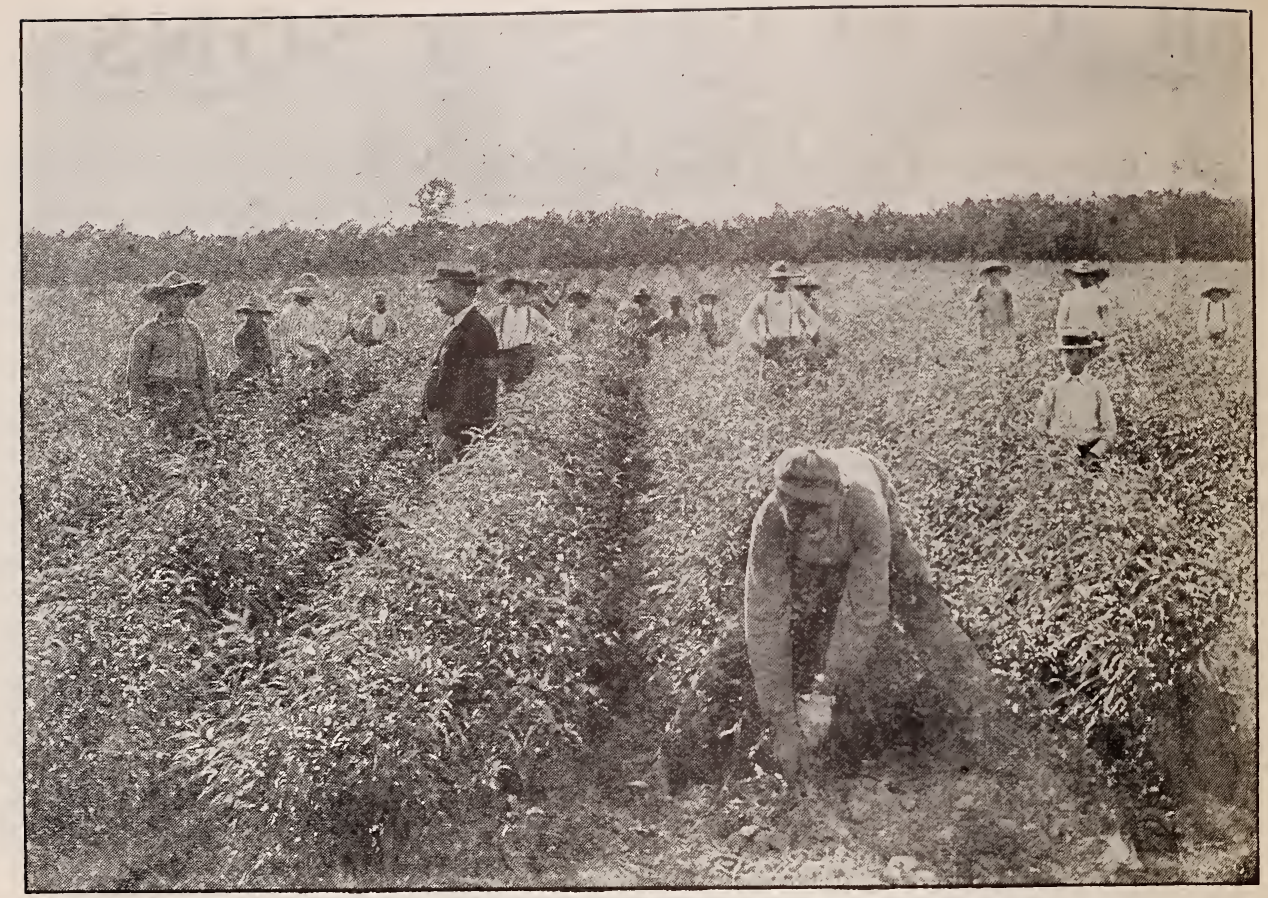

A NURSERY OF MORE THAN ONE MILLION PEACH SEEDLINGS

R. C. Peters directing work of budders during the month of August. At the Nurseries of R. C. Peters \& Sons, Ironshire, Maryland

\section{Building Up a Nursery}

How a large business was established from a comparatively small beginning.-Development of the Snow Hill Nurseries in Maryland.-The simple story of thirty years of successful effort by W. M. Peters and his sons.-Now shipping stock into nearly every important state, to Canada and to foreign countries.-From "American Fruits."

CHE nursery business of R. C. Peters \& Sons had its beginning in Delaware. IV. M. Peters, the father of Reese C. Peters, started in the business at Newark, Delaware, with his brother, Randolph Peters, known under the firm name of K. \& W. M. Peters. After being in business there for several years, the partnership was dissolved, and W. M. Peters conducted the nursery business on his own account at Centerville, six miles above Wilmington, in the same state.

In January, 1873, he purchased I, roo acres in Worcester county, Maryland, lying directly on the Sinepuxant bay, with a water front of nearly a mile. At that time, the nearest railroad or shipping point was Berlin, fourteen miles away.

On February 14, 1873, he placed his eldest son, Charles M. Peters, in charge of the land and had him plant, the same year, 55 acres with peaches, apples and cherries, the stock of which was furnished from his own nurseries at Centerville; fifteen acres were also devoted to strawberry plants. The next year he planted 40 acres of pear trees and 50 acres more in peaches and apples, all in orchard form. One year afterward, the railroad from Berlin to Franklin City, Virginia, was completed, which gave a shipping point within five miles of the farm, and the first strawberries were shipped from Wesley, Maryland, over this road, in 1874 . The completion of this road was 
largely due to the interest taken by W. M. Peters in raising stock by subscription from commission merchants in Philadelphia, New York and Boston.

In 1876 twenty acres were planted with peach seed, which really marked the beginning of the nursery business in IVorcester county. From this the planting of nursery stock was gradually increased, and in $1878 \mathrm{~W}$. M. Peters closed his busines out at Centerville, becoming a resident of Worcester county, and bringing his son, R. C. Peters with him. This gave him the assistance of both his sons in the nursery and orchard interests, which grew rapidly under this management, so much so that it became necessary to make a further purchase of land and locate the nursery interests where they would have the advantages of railroad facilities by having sidings run to the packing and storage houses.

To accomplish this Mr. Peters gave each of his sons an equal interest with himself in the nursery business, and together they bought a tract of land containing over five hundred acres situated at Ironshire, Maryland, two miles from Berlin on the main stage road leading down the Peninsula, said to be one of the finest tracts in the county, although it was in very bad shape at that time. This was in I887. They at once began the planting of nursery stock there, and the youngest son, R. C. Peters, moved on this property and took charge of it.

On July I5, I889, the death of W. M. Peters occurred, and the firm name was changed to IV. M. Peters' Sons. The sons assumed the entire stock and the property, and from that time until the present, improvements have been made until they now have one of the finest plants to be found anywhere in the state, with all facilities that could be desired for the carrying on of a first-class nursery.

The business of W. M. Peters' Sons has not been confined to its own neighborhood, but has extended to almost every state in the Union, and a great deal of this business has been direct with the commercial peach-growers in Ohio, Indiana, New Jersey, New York, Pennsylvania, Delaware and Maryland. In these states very large numbers of Peters' fruit trees have been planted, as well as in Kentucky, Georgia, Alabama, North and South Carolina, Virginia, West Virginia, California, Missouri, Kansas, Iowa and several of the territories. Michigan has over 500,000 peach trees of their growing planted, and Canada also has sent many customers. In fact the business has extended all over the United States, with a few shipments to foreign countries, among them Cape Colony, South Africa.

The firm of IV. M. Peters' Sons was mutually dissolved on June 27, I906, Charles M. Peters taking the farm on Synepuxent Bay, near Snow Hill, and all its contents; Reese C. Peters taking the farm and all its contents at Ironshire, Maryland, which comprised about the whole of the nursery business of the late firm. Reese C. Peters, on July I, associated with him his two sons, Alfred W. and Norman M. Peters, and the business is now carried on under the firm name of R. C. Peters and Sons Nurseries, P. O. and Shipping Station, Ironshire, Maryland. Bell 'phone in office. Telegraph office, Berlin, Maryland.

Dear Sirs:-I think it my duty to you to say a few words in praise for your way of doing business with your customers. April the IIth, I902, I received my first trees from you, 300 June Bud peach trees. They all started and grew, and today some of them have as much as two basketfuls per tree on them. This last April, I904, I received from you 527 peach, 4 cherry and 60 grape; they are every one growing nicely today. Some of the grapes have some fine bunches on them. I am very much pleased with the stock received from you. I have not seen Hall; he said if he did not lose over one dozen trees he would be satisfied. I said I expected all mine to grow, and they have. Would it be asking too much for you to tell me when and how you grow your grape cuttings? Yours truly,

Alfred Steward. 


\section{Terms and Conditions}

The Prices given in this Catalogue are for the quantities named, but five will be sent at the ten rate, six at the dozen rate, or fifty at the hundred rate.

Our Terms are Cash with the order or before shipment, except by special arrangement. Large buyers may with advantage send us lists of their needs for suggestions as to cost, etc.

Remit by Post-Office Money Order on Ironshire, Md., or by Bank Draft, Express Money Order, or Check ; cash sent loose in letters is at the risk of the sender. Letters may be registered when it is necessary to send cash.

Packing is Included in our prices, and is carefully done. The trees are delivered in good order to the railroad station at Ironshire, after which we disclaim responsibility, though we are always endeavoring to follow up shipments to destination, and find very little damage to happen in transportation. Our customers tell us our grading and packing are both superior.

Purchasers of Large Lots of peach trees will find it greatly to their advantage to write us for special prices, as we offer discounts in our wholesale business.

In Ordering, please give plainly your name, post-office address and state. Always tell us how you want trees to come, and name your express or freight station. Make orders on a separate sheet from your letter.

Car-load Lots are a specialty with us, and we have shipped many large blocks of trees, peach especially, to careful planters all over the country.

We are but Human, and, with all our care, may make mistakes, which we are quick to correct upon notification; but we must ask to be advised within five days of receipt of stock of any claim to be made upon any account, after which time we cannot consider them.

Our Shipping Facilities are excellent. We are on the line of the D. M. and V. branch of the great Pennsylvania system, which gives us unequaled facilities for reaching shipping centers. A side-track runs directly to our packing sheds, and we load cars in the most approved modern way, without having to handle boxes or bales by wagon. We are also but two miles from Berlin, Md., where a connection is made with Baltimore direct, via Chesapeake Bay.

Telegrams May Be Sent Us to Berlin, Md.

Our Guarantee of Genuineness.-While we exercise the greatest diligence and care to have all our trees, etc., true to label, and hold ourselves in readiness, on proper proof, to replace all trees, etc., that may prove untrue to label, free of charge, or refund the amount paid, it is mutually understood and agreed to between the purchaser and ourselves that our guarantee of genuineness shall in no case make us liable for any sum greater than that originally received for said trees, etc., that prove untrue.

W. M. Peters' Sons, Snow Hill, Md.

Mount Airy, GA., September I2, I903.

Dear Sirs:-Please put in your order book, to be shipped to John P. Fort, Cornelia, Ga., by express, sixty $(60)$ one-year-old peach trees from $3 \frac{1}{2}$ to 4 feet-Geary's Hold-on. This peach seems to succeed in this locality. It is of the Smock variety and resembles Beer's Smock, so as not to be easily distinguished from it While not the best of peaches, the time it ripens makes it valuable. No fruit of importance this year. My orchard grown from your stock still looks very well and is much admired. It is now in its fourth year. Trees meet in row, 20 feet apart. Yours truly, JOHN P. FORT. 


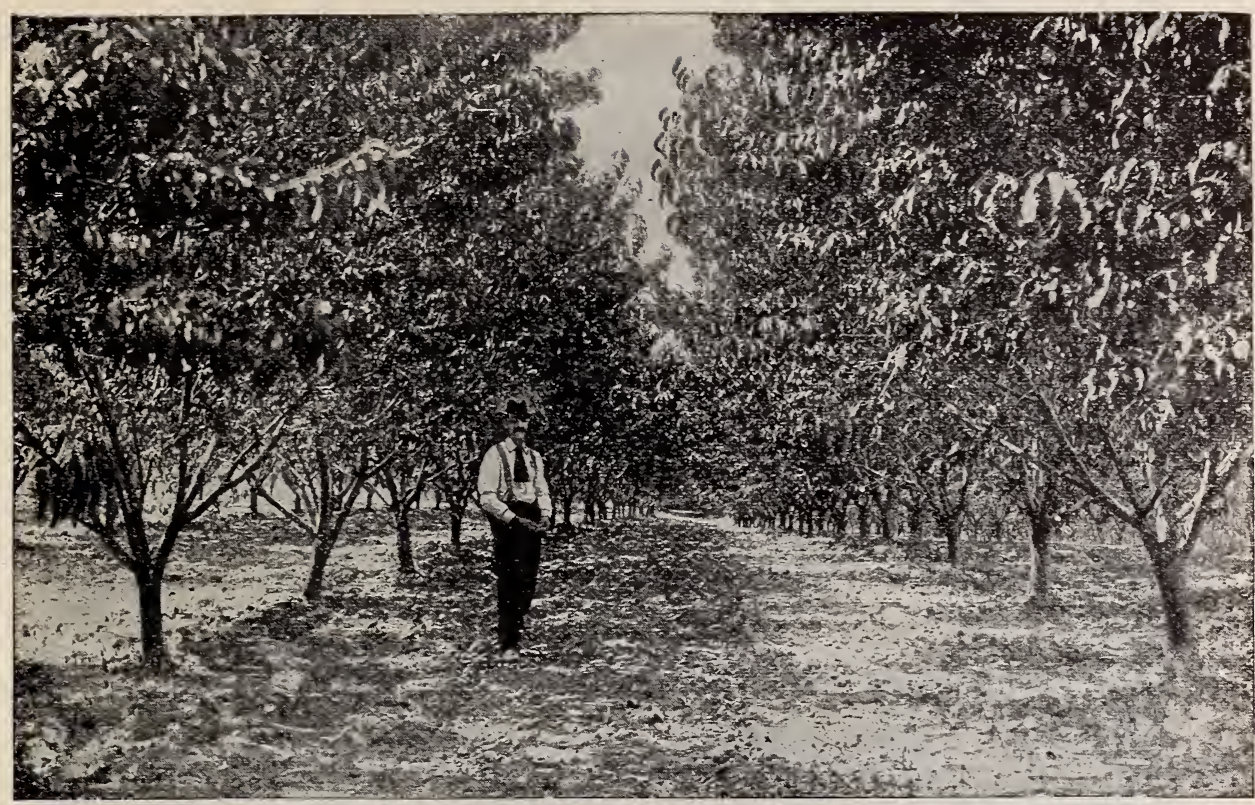

VIEW IN ORCHARD OF MR. B. F. COCKLIN, NEAR BOWMANSDALE, CUMBERLAND CO., PA., (ABOUT I2 MILES SOUTHWEST OF HARRISBURG). PLANTED WITH OUR PEACH TREES.

\section{New Departure in Peach-Growing}

\section{PROPAGATING NEW VARIETIES TO ORDER}

We make a specialty of propagating and growing new and valuable varieties of Peaches for our customers, who have, by their experience and knowledge, learned that their soil and climate are especially adapted to certain kinds of Peaches, and who have originated new varieties which give promise of yielding the best returns in their orchards. It is well known that not all varieties are adapted to all localities. In some places one kind may do all that the most captious might expect of it, while in another it may be a flat failure. The intelligent orchardist knows how to study these conditions and to take advantage of them. IVe want to help him. IVe, therefore, have made it a distinct branch of our business to lend this aid by propagating, for those who request it, new varieties of Peaches specially adapted to the conditions surrounding certain places, and those who find like conditions in their localities will do well to take advantage of the practical knowledge and experience embodied in these new varieties.

Below we list five new varieties which have been propagated under these conditions by special request of the introducers, to whom we refer for specific descriptions, etc.

WILKLOW SEEDLING. Introduced by A. P. Wilklow, Highland, Ulster Co., N. Y. A white Peach with crimson blush; large size, quality of the best and very rich in flavor.

GARRISON'S LATE YELLOW. Introduced by E. Y. Garrison, of Cheswold, Del. A large yellow Peach ripening after Crawford's Late. Highly prized.

LAMBDEN. Introduced by IValter T. Massey, Smyrna, Del. A large yellow Peach much above the average in quality.

MASSEY'S YELLOW. Introduced by Walter T. Massey, Smyrna, Del. A fine large yellow Peach of excellent quality.

MAYFLOWER. Introduced by J. Van Lindley Nursery Co. The most beautiful Peach ever grown, being a bright red all over, and a week earlier than Sneed. It has been given the hardest kind of test, and has responded nobly. It is a strong, thrifty, upright grower ; is inclined to overbear and must be thinned for best results. One of the best shippers known and wherever exhibited the public has clamored for more. Its beauty, earliness and exquisite flavor make it a most valuable market Peach. 


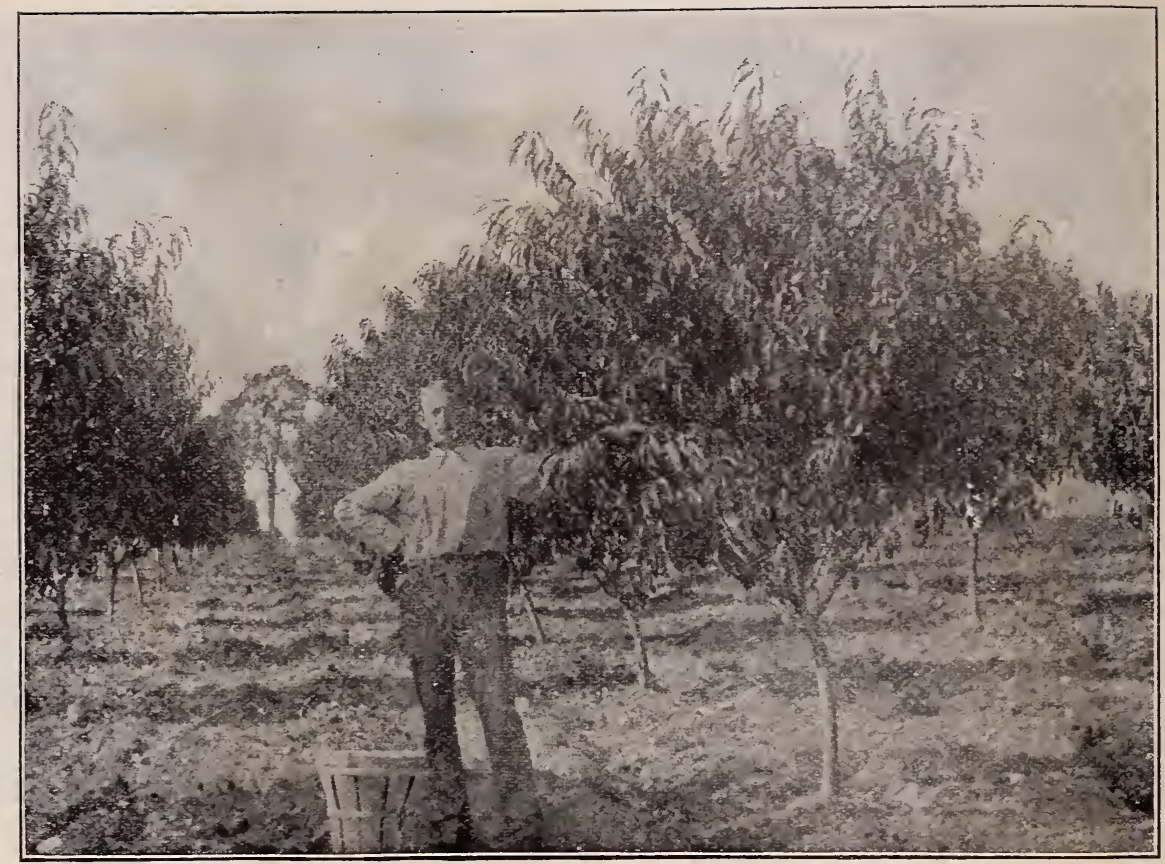

VIEW IN ORCHARD OF MR. A. P. WILKLOW, HIGHIAND, N. Y.

\section{PEACH TREES}

The Peach is not a weed, and will not care for itself; it needs care, and pays for that care most bountifully. No fruit tree responds more quickly to intelligent cultivation, or more rapidly deteriorates with slipshod handling. During a recent fruiting season in a great Pennsylvania Peach orchard (grown from our fruit-bearing trees), the owner was asked: "What have you to say of commercial Peach-growing, after many. years of trial, with good crops and bad, high prices and low?" His answer was emphatic: "I am satisfied with the profit and pleasure to be had in Peach-growing and my youngest son has just bought a farm of 150 acres to plant to Peaches." This successful grower was one of the active men, who cultivated and pruned his trees, fought the insect enemies, thinned the fruit, picked and packed with honest care, and therefore obtained satisfactory profits.

The lesson is plain, and indicates that never was there a better chance for satisfactory profits from Peach-growing if the trees are well grown and handled with intelligent care. For our own Peach trees, we can say that they are budded from fruiting trees, on strong natural stocks, grown in land which is specially adapted, and which has never had Peaches grown upon it before. Our methods of budding are the outcome of a generation's study and experience, and the many letters from successful growers show that our trees are superior in every respect. Not a trace or disease, either the dreaded "yellows" or "rosette," or of insects, from San José scale up, has ever appeared in our stock.

Those intending to set out large numbers of Peach trees are requested to write us freely, both for suggestions and special prices.

Prices of June-Budded Peach Trees. General list of varieties.

\begin{tabular}{|c|c|c|c|c|}
\hline 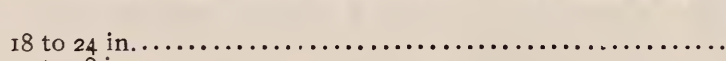 & $\begin{array}{r}\text { Each } \\
\text { \$ \$0 10 }\end{array}$ & $\begin{array}{l}\text { 10 } \\
\text { \$0 } 75\end{array}$ & $\begin{array}{c}100 \\
\$ 600\end{array}$ & $\begin{array}{r}\mathrm{I}, 000 \\
\$ 40 \text { O }\end{array}$ \\
\hline & & & 500 & $35 \mathrm{co}$ \\
\hline
\end{tabular}

Admiral Dewey. A perfect freestone ; ripens with the Triumph ; flesh is yellow, brighter color on the of uniform color and texture to pit. Has better form and symmetrical grower, and as near perfection as we can obtain in a single variety. 


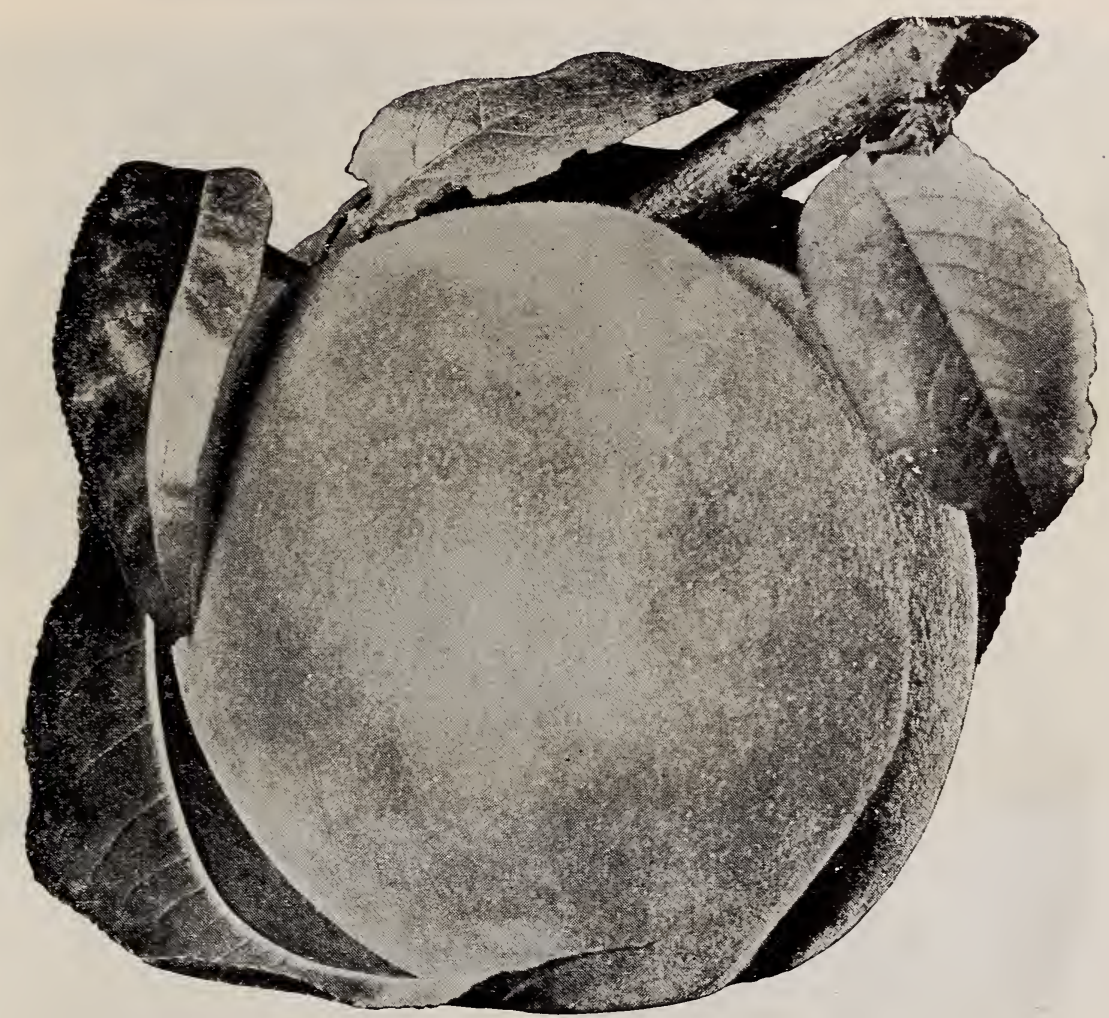

FITZGERALD PEACH

\section{NEWEST VARIETIES OF PEACHES, continued}

Bokbara. A Russian variety, which is claimed to be the hardiest Peach grown ; in fact, it has withstood a temperature of $28^{\circ}$ below zero without injury. It is a beautiful yellow Peach, with bright red cheek; perfect freestone; delicious flavor; its exceedingly tough skin makes it a splendid shipper.

Connet's Southern Early. A seedling of the old Chinese Cling, which originated in Guilford county, N. C. It has extra-large fruit of a cream-white shade, having a beautiful blush next to the sun. It is one of the most delicately colored Peaches grown, and a clear freestone with small seed. Of fire quality, and borne in profusion early in June upon trees noted for their strength and vigor. Introduced by the originator of the famous Elberta.

Delaware. There has long been a demand for an extra-early large Peach, and in this variety we believe the most captious will find their ideal. It is a beautiful white Peach, of good color, with a bright red blush on the side; as large as Mountain Rose, and ripens among the earliest. It has been thoroughly tested and proved to be a variety distinct from any other early Peach. It ships in first-class condition, which makes it particularly valuable as a market variety. In flavor it is of the very best, and, coupled with its beauty and earliness, it is undoubtedly one of the most satisfactory Peaches to grow.

Denton. The fruit resembles that of Elberta, but is a full week to ten days later in season. So far it has proven remarkably certain as a bearer, bearing when all other kinds fail. Is equally as large as Elberta, and even more reliably productive.

Fitzgerald. This is an extremely valuable new Peach. It is of Canadian origin. Fitzgerald. Of very large size, it is at the same time of magnificent quality and a perfect freestone. One peculiarity is the extreme smallness of the stone. Its flesh is a 


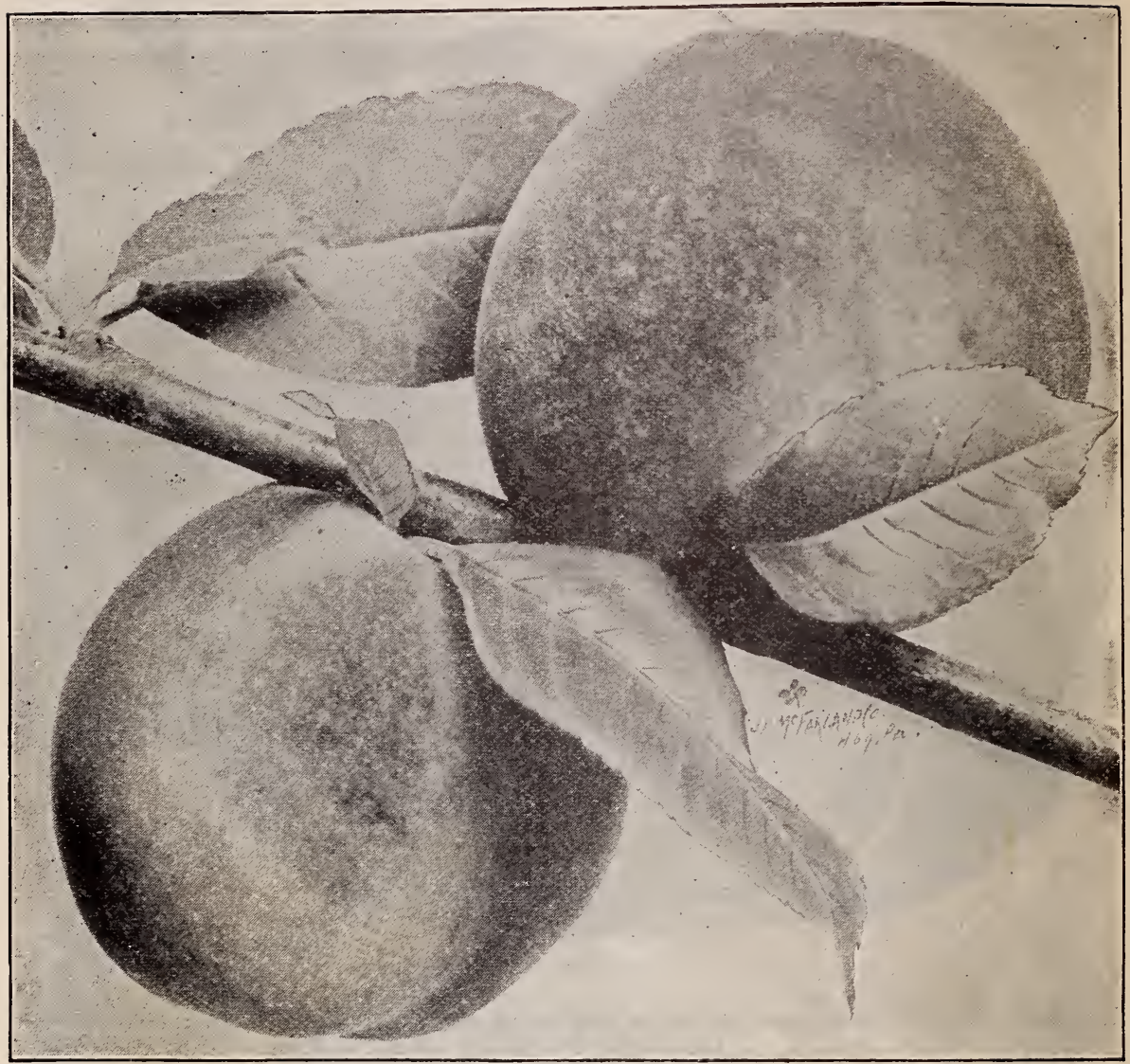

FRANCES PEACHES

NEWEST VARIETIES OF PEACHES, continued

beautiful shade of yellow, very firm, rich and juicy. It is a splendid shipper, and makes a beautiful appearance in market. Four of these Peaches weighed, upon a test, fully two pounds. It is very early in the region from whence it came, catching the market at a most opportune time.

Frances. One of the handsomest Peaches ever grown, being of a beautiful shade of Frances. yellow, covered almost entirely with brilliant red. In size it is about the equal of Elberta, average specimens measuring nine inches in circumference. It is very productive : the originator cut a branch 9 inches long on which were growing nine full-sized Peaches. It is a true freestone, with particularly solid flesh, and as a "shipper" is absolutely without a rival.

Gold $\mathscr{H}$ Cine. Originated in Michigan, and is extremely productive. The fruit is round or nearly so, having no point or bunch at center. It is large, yellow, with good rich coloring, resembles Late Crawford and ripens at the same season.

Gordon. This is the finest late yellow Peach in existence. It is of medium size, beautiful yellow color, firm texture and delicious flavor. It ripens the latter part of September and will keep a month. It is unexcelled as a shipper, and could easily be shipped to Europe. The fruit is unusually handsome and colors up fully before ripening, keeping for several weeks. It comes when all other marketable peaches are gone, and hence has a clear field. 


\section{R. C. Peters \& Sons Nurseries, Ironshire, Md.}

N'EWEST VARIETIES OF PEACHES, continued

Hiley. (Early Belle). This seedling of Belle of Georgia is much like its parent in Hiley. size, color and beauty, having the same vigor of tree and hardiness of fruitbuds, but ripens its fruit nearly a month earlier. It is a large, creamy white Peach, with rich blush on sunny side ; of fine quality and a good shipper. July 15.

Holderbaum. As a thrifty, hardy Peach, the Holderbaum takes first place. It originated in the mountains of Pennsylvania, where 26 to 28 degrees below zero is often the temperature the original tree has stood. This hardiness is the result of the heavy bark the tree carries, and the faculty it has of ripening its wood as fast as the growth is made. It is a giant among Peaches, many specimens measuring $\mathrm{I} 2$ to $\mathrm{I}_{4}$ inches in circumference, and is a perfect freestone, with a most delicious flavor. One peculiarity it has, of not opening out its blossoms like other varieties, makes it almost frost-proof, as the young fruit is protected by a heavy, moss-like fuzz. It is a splendid shipper, and altogether one of the most desirable Peaches for the fruit-grower to plant.

Klondike. Beautiful as Mountain Rose, with quality equal to Oldmixon, and ripening Klondike. with Smock. Large size, white skin with brilliant red over-cover; white flesh, sweet, juicy, delicious flavor; perfectly free, bright red at stone and free from fiber. October Io.

Victor. One of the earliest varieties known, of medium size, ripening before Sneed. A seedling of the Chinese Cling, crossed with Spanish blood.

$W$ addell. As an early market Peach, this variety is of great value. The tree is a good, strong grower, of Chinese type, and very profuse in bearing. The fruit is medium to large, of oblong shape, and of a rich creamy white, with blush on the sunny side; of excellent quality and a very goud shipper. This is a successful Georgia variety.

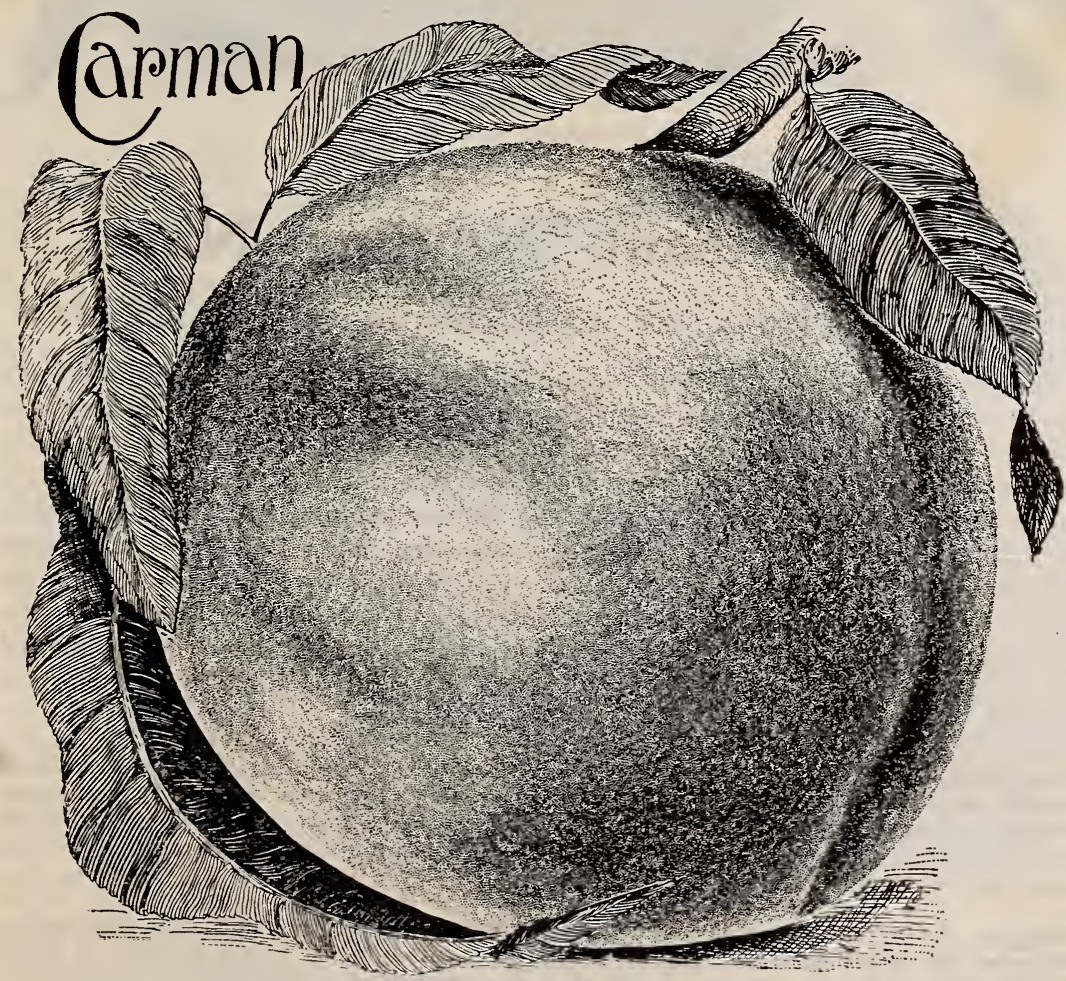

CARMAN PEACH (see page IO) 


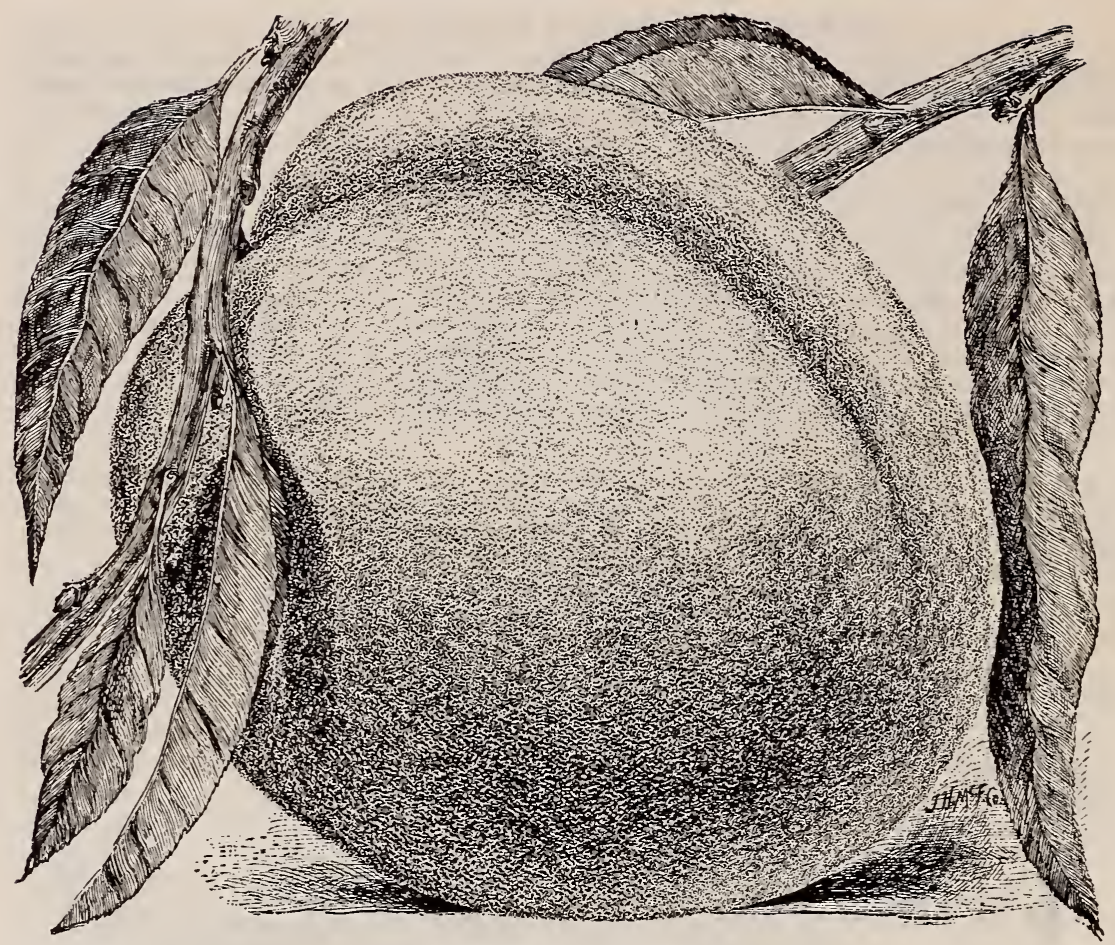

GREENSBORO PEACH

\section{Our Pennant-Winning Nine}

\section{SELECT VARIETIES FOR HOME OR ORCHARD CULTURE}

A perusal of our list of Peaches, on the following pages, will show that we are heavy growers of all the best varieties known; but there are many among our customers to whom the list does not appeal in the same manner as it does to expert Peach-growers, and to whom the long list of varieties is only confusing. For their benefit, and as a suggestion to growers who will recognize the intrinsic value of the splendid varieties here offered, we present our "Pennant-winning Nine." Commencing with Greensboro, which is the earliest of all early Peaches, the list continues through the summer in successive ripenings until, at the advent of cold weather, comes Bilyeu's Late, thus furnishing an uninterrupted supply of this most luscious fruit, and, if planted in sufficiently large quantities to make blocks of each, will be found to provide good and showy fruit for marketing. See page 12 for prices.

Greensboro. The very earliest of the early Peaches, preceding Alexander, which Geensolwar heen quoted as a standard of earliness, and is an almost perfect freestone. It is beautiful in appearance, being covered with light and dark crimson, shaded with yellow. The flesh is white, very juicy and of extra quality. The tree is a good grower and the fruit a splendid shipper.

Carman. A new variety, which is bound to meet with favor. It is thoroughly hardy, rot-proof, ripens very early-at the same time as Early Rivers. It is an excellent market Peach; large and round, with a creamy skin, red blush on sunny side. Its flesh is white, rich, tender and melting, and it is a very profitable market Peach. 
MCountain Rose. A superb, eariy, white-fleshed Peach, which yearly adds to its reputation as the best of its season for home or market. Ot large size, it is also of fine appearance, the delicately flushed skin being brightly shaded and marked with red. The flesh is white, and parts freely from the stone; it is of especially rich flavor, with much juice. The tree is of good growth and very productive. Altogether, Mountain Rose fills a place in practical Peach-growing untouched by any other variety, and in spite of the many new introductions holds its own among the best.

Champion. A particularly hardy seedling of Oldmixon, from the IVest, which is Coted for the hardiness of its blossoms, thus insuring a good yield in spite of heavy spring frosts. It is a very large, handsome Peach, with a creamy white skin and beautiful red cheek. In flavor it is exquisite, and is a true freestone. Ripens the middle of July.

Reeves' Favorite. Not a new Peach, but one thoroughly tested, and with a place among knowing orchardists as one of our very best midseason yellow freestone varieties. The bright yellow skin bears on its surface a jacket of bright red; the size is large, and the shape is roundish oval. The flesh is deep yellow, running into red at the stone ; it is also highly-flavored, juicy and melting. The tree is vigorous, very hardy and abundantly productive. It is apt to overbear, and thinning the fruit is very beneficial.

Elberta. Here is the king of market Peaches! It has been said that Elberta would Glberta. not "color up " in the North, though most beautiful in its Georgia home; but those who saw it ripen in a great Connecticut orchard could certify to its brilliancy, as well as to its size and form. It is an ideal market Peach, and a royal fruit, from its yellow and red skin to its red stone. The size is enormous, the quality excellent, the tree vigorous and productive. Better still, the fruit market has never yet had too many of this sort, and those who plant and grow it with care will get golden dollars for golden Elbertas.

Chair's Choice. A large and handsome late yellow Peach, with conspicuous red Cheek. The flesh is deep yellow running to red at the stone, and is of high flavor, juicy, melting; freestone. Tree is hardy, vigorous and productive.

Fox's Seedling. This native of New Jersey, where it has always proved very productive and in all respects is a very satisfactory Peach to grow. It is rather late, and a good freestone. The fruit is round, slightly compressed. The skin is white, with a red cheek. The flesh is melting, juicy and sweet, and thoroughly delicious.

\section{Bilyeu's Late October}

The last Peach to ripen, but by no means the least in quality. It is of large size, is a perfect freestone, and in richness of flavor can hardly be surpassed. By reason of its lateness is a sure bearer, and the tree is remarkably thrifty and productive, bearing large crops of beautiful fruit with red cheeks.

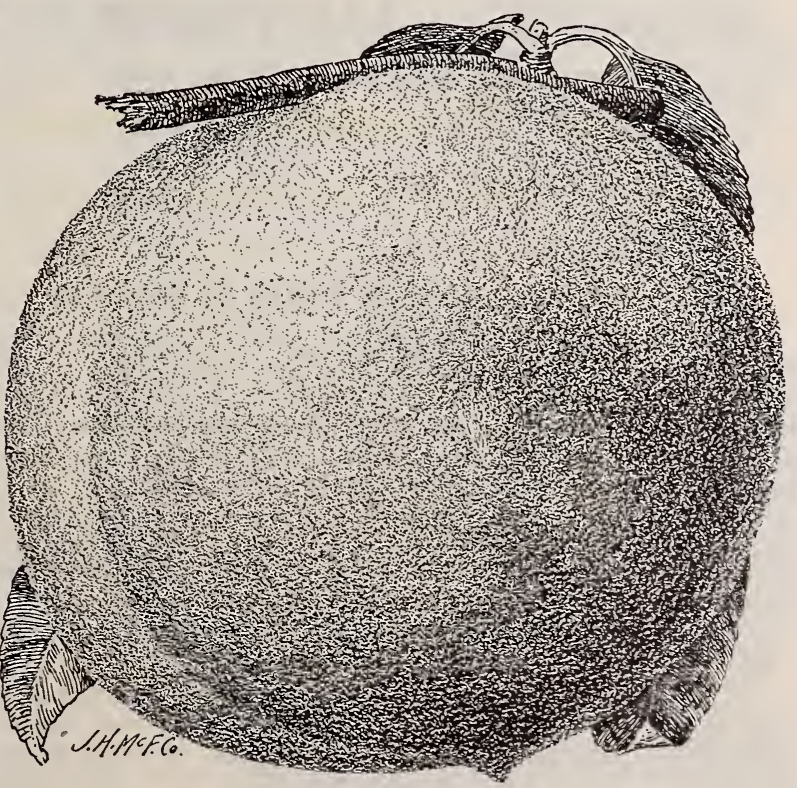

MOUNTAIN ROSE PEACH 


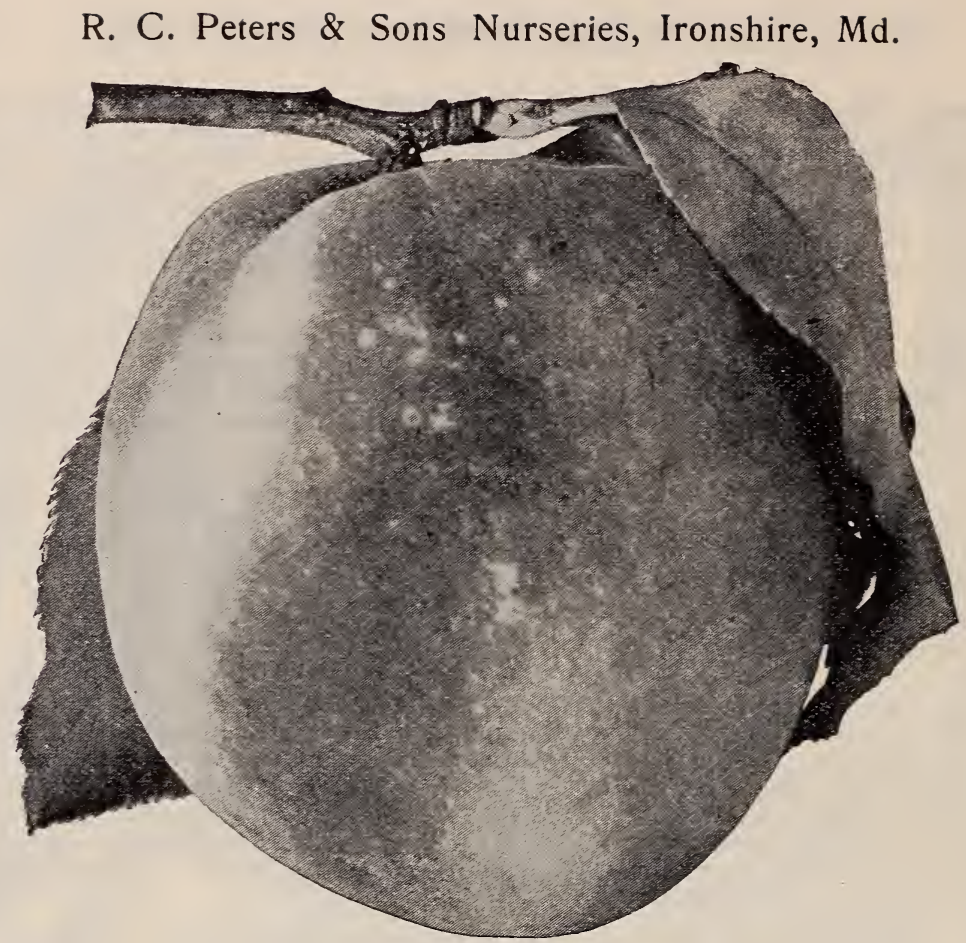

BELLE OF GEORGIA PEACH

\section{STANDARD VARIETIES OF PEACH TREES}

Prices, except where noted, with description. All first-class trees

\begin{tabular}{|c|c|c|c|c|}
\hline Prices, I-year-old trees. & Each & Per Io & & $\mathrm{I}, 000$ \\
\hline 5 to 7 feet... & \$o 15 & $\$ 125$ & $\$ 800$ & $\$ 7000$ \\
\hline 6 feet...... & 12 & I 00 & 700 & 6000 \\
\hline 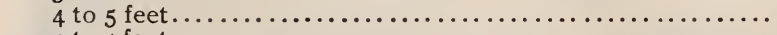 & IO & 80 & 600 & 5000 \\
\hline 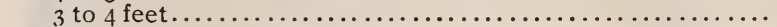 & 08 & 70 & 500 & 4000 \\
\hline . & o5 & 40 & 350 & 3000 \\
\hline hht, $1 / 2 \mathrm{t}$ & 04 & 30 & 250 & 2000 \\
\hline
\end{tabular}

\section{VARIETIES ARE NAMED IN ORDER OF RIPENING}

Greensboro. See description in our "Pennant-winning Nine," page ro. ,

Sneed. Up to the present time this is one of the earliest Peaches known, ripening in Georgia in May. Of medium size, it is somewhat oval in shape; rich, creamy white, with beautiful red blush on sunny side. Ripens very evenly, and has a great advantage over other early varieties, inasmuch as it is not subject to rot. As an early market Peach, it is one of the most valuable grown.

Alexander. Considered one of the best early Peaches, being of large size, nearly round, with a shallow suture; skin greenish white, nearly covered with deep red, turning to almost purple in the sun; flesh white, firm, juicy and sweet, adhering slightly to the stone, which is small.

Amsden June. Very much like Alexander. Medium size, highly colored skin and white flesh ; freestone. One of the earliest.

Triumph. The first yellow Peach to ripen. It has a clear yellow skin, overlaid with bright red dots and blotches. The flesh is yellow, dashed with red near the stone, from which it parts readily when fully ripe. It ships in fine shape. The tree is a tremendous grower, and bears very young; even 2-year-olds have had good fruits.

Belle of Georgia. Very large ; skin white with red cheek ; flesh white, firm and of excellent flavor ; fruit uniformly large and showy; tree a rapid grower and productive; very prolific; free. July I to 15. 
Early Rivers. A large Peach of a pale straw-color, with a delicate pink cheek ; flesh melting, very rich. Middle of Juiy.

Hale's Early. A standard early sort, coming into bearing in July. Particularly attractive, with smooth, white skin, delicately marbled with different shades of red on the sunny side. Rots in some locations.

Michigan Early. A western variety which has given great satisfaction. Splendid as a market Peach, as well as for canning; hardy and prolific.

Yellow St. John, or Fleitas. Called by some in the South, May Beauty. A large, round, orange-yellow Peach, with deep cheek; very juicy and sweet; yellow flesh ; freestone. Middle of July.

Large Early York. Considered the very best of its season. It has many synonyms and is one of the most popular Peaches for garden culture. A regular bearer, of high flavor, sweet and delicious; and the tree is particularly hardy and vigorous; fruit is large and round, with broad suture ; skin yellowish white, with beautiful blush; freestone. August.

Mountain Rose. See description in our "Pennant-winning Nine" list, page I I.

Champion. See description in our "Pennant-winning Nine" list, page I I.

Conkling. A large, yellow variety, with red cheek. Ripens a trifle later than Crawford's Early.

Foster. A good, hardy, northern Peach, originating near Boston. Very large and round, about the same as Crawford's Early (before which it ripens) in size, but of much better quality; a yellow freestone.

Crawford's Early. The true Crawford's Early, of which we have a large guaranteed stock, is a most valuable market Peach. It is a magnificent, yellow-fleshed fruit, of large size and highly colored. The variety was almost extinct, but it has been revived better than ever. Many growers have been raising a small, yellow-fleshed Peach and calling it Crawford's Early, by which they have done great injustice to this splendid fruit. Moderate grower and extremely productive. Freestone.

Mary's Choice. Not a very heavy bearer, but makes up in quality what it lacks in quantity. Large yellow freestone with red cheek. A truly "fancy" peach, especially for careful growers.

Reeve's Favorite. See description in our "Pennant-winning Nine" list, page II.

Kalamazoo. Medium size; yellow, crimson cheek; pit small; of very high quality, and much esteemed in Michigan.

Lewis, Seedling. One of the earliest freestones; medium to large ; greenish white with red cheek. Flesh white and juicy ; pit small.

New Prolific. As its name indicates, a very prolific variety of excellent quality ; fruit golden yellow with red cheek; large and handsome. First of September.

Chinese Cling. A favorite Peach in the Southland. Medium early; of large size ; creamy white, with beautiful blush ; flesh of the very highest quality ; indeed the standard of richness among Peaches.

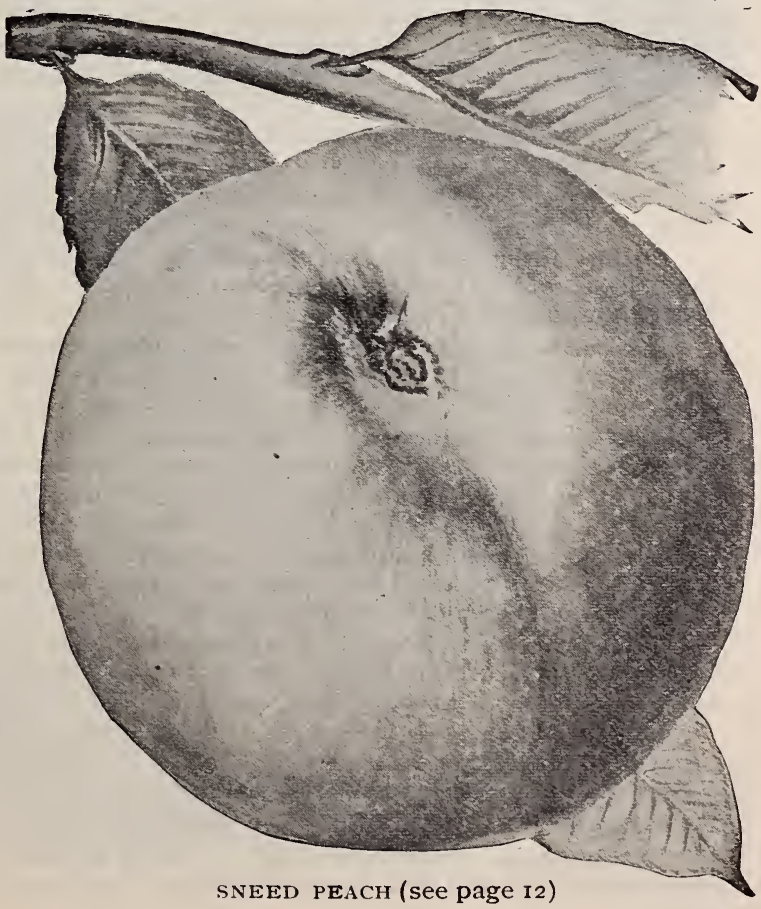




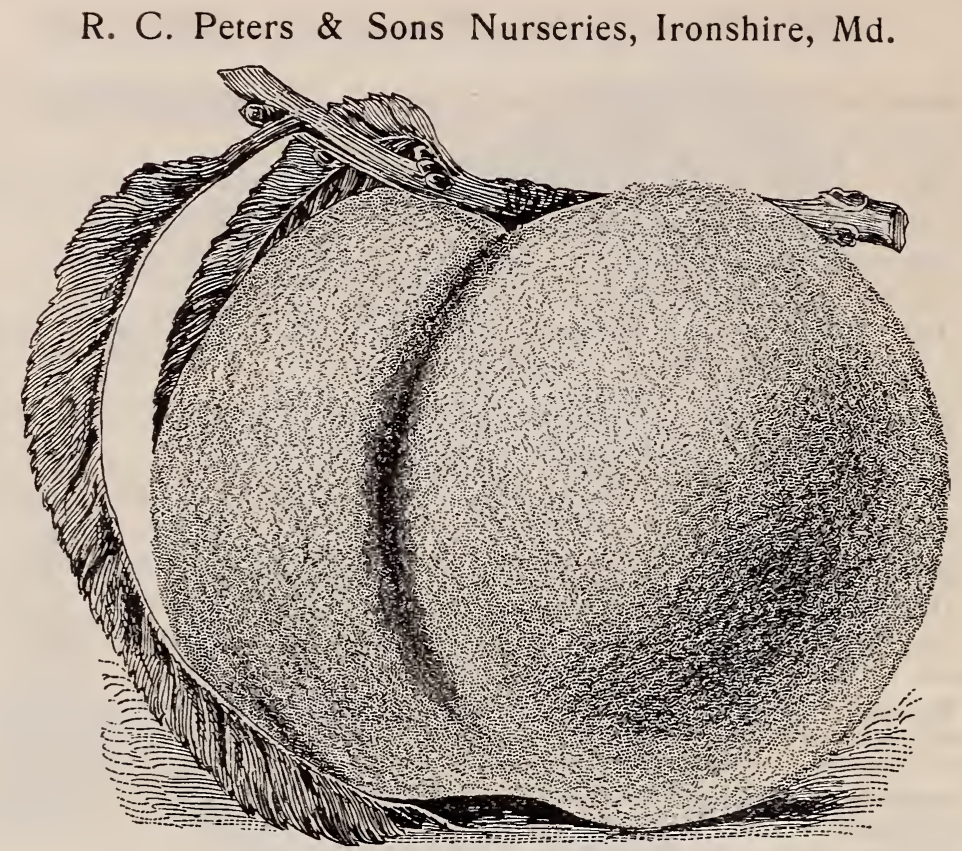

CROSBY PEACH

Elberta. See description in our "Pennant-winning Nine" list, page II.

Matthews. Large size, above medium; shape similar to Elberta but a little longer. Skin golden yellow, streaked with red; flesh yellow, firm and of excellent flavor. Ripens three weeks later than Elberta. Perfect freestone.

Crosby. A most distinct Peach, both in flavor and habit. It is flattened in form with a deep suture. Skin is deep yellow, flushed heavily with red. The flesh is rich, luscious and sugary. Freestone, with an exceedingly small pit. Tree is hardy and vigorous and will stand a great deal of thinning out-in fact, it improves both tree and fruit to do it.

Moore's Favorite. Resembles Oldmixon, but ripens a few days earlier. Fruit large, white, with red blush; freestone. Not a heavy bearer, but superfine in quality.

Oldmixon Free. One of the old standard market sorts. A large Peach, with white flesh and red cheek; a perfect freestone; very productive and profitable. Ripens just before Crawford's Late.

Powell's Mammoth. As its name implies, mammoth in size ; a beautiful yellow freestone, with red cheek; good in quality, with firm flesh and rich, vinous flavor. Some specimens weigh 12 ounces. Latter part of August.

Red-cheek Melocoton, or Melagatune. Almost too well known to require description. Under various names, hundreds of thousands of bushels are raised every year; and it is the parent of many of the modern varieties. Fruit is large, roundish oval; yellow skin, deep red cheek; a perfect freestone. First of September.

Stump-the-World. Large; creamy white, with red cheek. This is a highly flavored Peach, an old freestone variety, and very prolific. Resembles Oldmixon. Free, and comes into bearing late.

Thurber. A seedling of the Chinese Cling, and ripe about the middle of July. Originated in Georgia. Fruit large and round, slightly oval; creamy white, shaded and mottled with pale red; fine-grained flesh, juicy and melting ; freestone.

Engle's Mammoth. An extremely large Peach. Particularly valuable for Michigan, where it originated. A beautiful yellow, with a rich red blush, and splendid, firm yellow flesh; pure freestone; rich in flavor and juicy.

Late Mixon. Very similar to Oldmixon, but later; freestone.

Christiana. A southern variety, ripening in September. A very large fruit, with clear yellow skin and flesh; delicious flavor; freestone. 
Susquehanna. (Called Griffith by some.) A large, handsome freestone, very popular with those who have raised it. Nearly round, with rich yellow skin and beautiful red blush almost covering it. Flesh yellow, sweet and juicy. First of September.

Crawford's Late. A standard sort, which holds its own with the best of its competitors. Considered by some as the very best of its season and as a yellow-fleshed Peach. Few Peaches excel it as a profitable market fruit. Freestone.

Lemon Free. Of lemon-shape, oblong, pointed at the apex; pale yellow when ripe ; of excellent quality ; immense size ; exceedingly productive.

Wheatland. Very large, roundish; bright yellow, with a crimson cheek; yellow flesh; very firm and juicy; free, strong and prolific. September.

Chair's Choice. A late yellow-fleshed Peach. See description in "Pennantwinning Nine" list, page II.

Brandywine. Large, yellow, firm. A very desirable freestone Peach ; similar to Crawford's late in looks, but about one week later than that variety. It has been well tested for years, and has always exceeded expectations.

Lorentz. A yellow Peach of very large size, ripening late. It is of good quality and seems also to possess frost-resisting qualities, as it produces a good crop.

Globe. A Pennsylvania variety of great size and beauty, and of exquisite flavor. Globular in form, all the fruit on the tree running uniformly large; golden yellow, with red blush; flesh firm and juicy, yellow, shaded with red toward the stone, from which it frees itself perfectly. A splendid shipper.

Hill's Chili Improved. This variety was first called Connecticut, and now has some thirteen different names. Of New York origin ; hardy, vigorous and productive ; of a medium size, oval, with slight suture ; in color a deep yellow, shaded with dark red; flesh deep yellow, red at the stone ; freestone. Last of September.

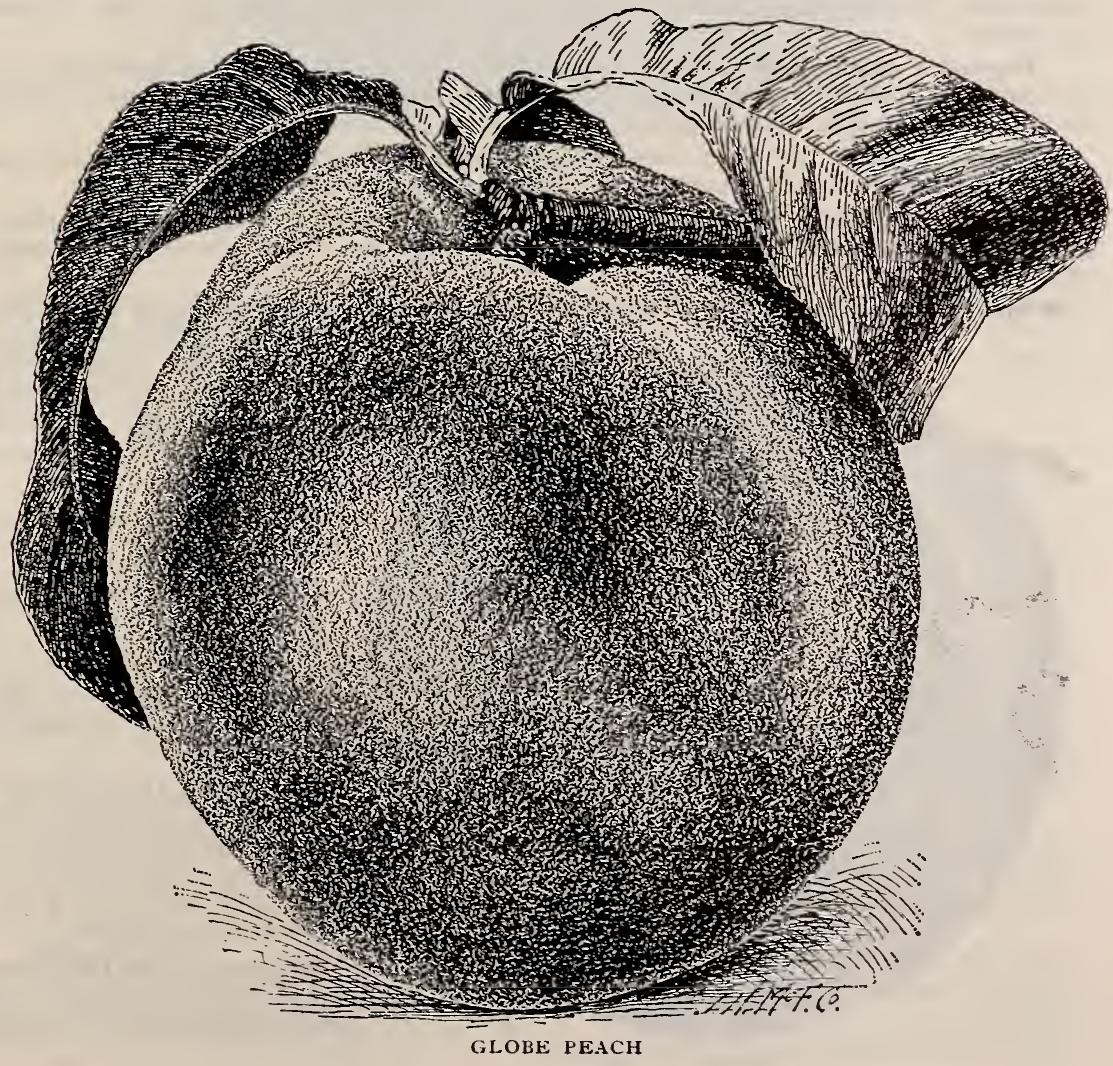


Prize. A very large, yellow freestone; one of the most profitable of the late varieties, and wherever it is grown is a most popular Peach.

Fox's Seedling. See description in our "Pennant-winning Nine" list, on page II.

Beer's Smock. One of the most popular Peaches grown for canning and evaporating. Very productive, and of good quality. Ripens rather late, with Brandywine.

Geary's Hold.On. Very much like Beer's Smock, but a little larger; yellow, with red blush, and a very profitable peach to grow; a late variety, ripening later than Brandywine.

Salway. A rather large yellow freestone variety, which is particularly adapted to light, sandy soil. A late Peach, which comes into bearing about September I.

Wonderful. Extra large, and of a rich, deep yellow, covered with carmine ; freestone; yellow flesh, firm and high-flavored; very prolific. Late September and October.

Steven's Late Rareripe. A very popular New York Peach, which grows to immense size when thinned; very hardy. Freestone. Late.

De Course Heath. Very large; clingstone; very late, and of a peculiar transparent appearance, with fine, clear skin and slight pink tinge on the sunny side. In shape much like White Heath Cling. Considered valuable in Maryland.

McCollister. A yellow Peach of immense size. A cross between Crawford and Smock, having the good qualities of both of these standard sorts. Very popular where grown.

Wilkin's Cling. A seedling of Heath, but larger. Sometimes called Ringgold Mammoth. Its originator thinks it the most valuable Peach in cultivation. Ripens in October.

Taylor's Mammoth Cling. A magnificent white clingstone of immense size, and chiefly valuable for preserving. Promises to be superior in every way to White Heath Cling. Last of September.

Willet. One of the finest large yellow Peaches grown; of the Crawford Late type. Tree is very thrifty, upright and vigorous. Last of September.

Picquet's Late. A Georgia variety, where it comes into bearing in September. Fruit is very large, sometimes lop-sided; yellow with a red cheek; Hesh yellow, sweet and of high flavor; freestone.

White Heath Cling. Very large and oblong, with white skin and red blush;

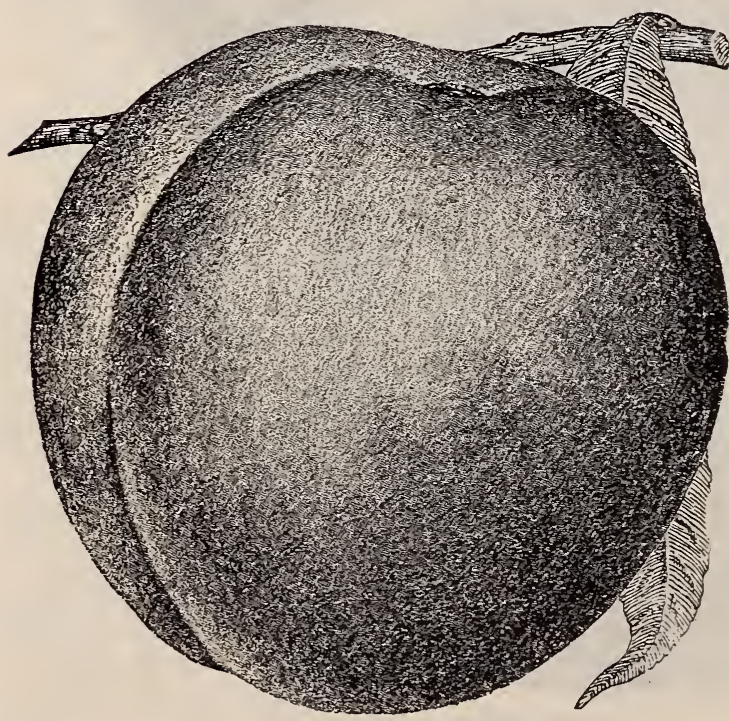

FOX'S SEEDLING PEACH greenish white flesh, very tender and juicy. Very popular in the South and West, where it is extensively planted. Tree very hardy and vigorous. October.

Heath Cling. See White Heath Cling.

Bray's Rareripe.Large, creamy white, flushed with crimson; flesh white, rich and juicy. Regular and abundant bearer; planted largely along the Hudson for late ripening.

Henrietta (Levy's Late). A beautiful clingstone, with remarkable keeping qualities. It is bright yellow, of large size, and is very productive and excellent.

Bilyeu's Late October. See description in our "Pennant-winning Nine," on paze II. 


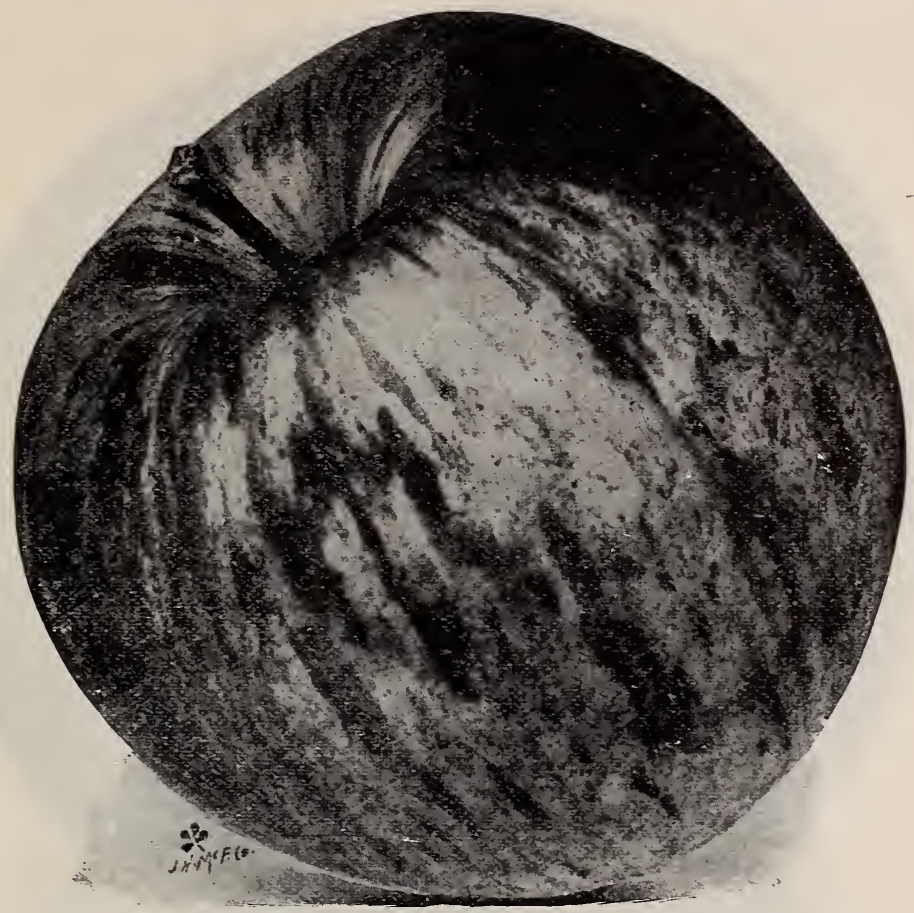

BEN DAVIS

\section{APPLES}

The past few years have witnessed the shipment abroad of thousands of barrels of American Apples. There has been much profit in these shipments to growers of good fruit, and much disappointment to others. The point to be observed is that, for any market, Apples must be grown with attention to keeping the trees strong and healthy, and the fruit free from insect ravages.

Our selection of varieties is of the best only.

\begin{tabular}{|c|c|c|c|}
\hline Price of Trees, Except Where Noted & & & \\
\hline n.m. & & $\$ 200$ & $\$ 18$ oo \\
\hline 5 tc & & & \\
\hline $\mathrm{n}$ & $\begin{array}{l}18 \\
15\end{array}$ & I1 50 & $\begin{array}{ll}1200 \\
10\end{array}$ \\
\hline e, 3 & 12 & I oc & $8 \mathrm{co}$ \\
\hline & 08 & & 600 \\
\hline
\end{tabular}

MAMMOTH BLACK TWIG. (Called Paragon by some growers.) One of the finest winter Apples grown. It originated in Lincoln, Tennessee, and is, without doubt, one of the most valuable and profitable Apples in the market. The tree is a strong grower, and makes a handsome addition to the nursery or orchard. The fruit is very large, roundish, and of a rich, dark red. We have an especially fine lot of this variety, and can guarantee satisfaction. October to February.

STAYMAN'S WINESAP. A favorite cider Apple, and at the same time a valuable variety for dessert or general winter use. It is of medium size and conical form ; mostly covered with red on yellow ground, and with fine, crisp flesh, with a rich high flavor. Keeps till May.

BEN DAVIS. A beautiful, large Apple; greenish yellow, striped with red; very handsome and a late keeper. It is one of the very best Apples for market-growing, and forms a staple with the great western orchardists. The tree is upright, handsome and very productive. IVe have a large and fine stock of this desirable variety, and commend it to all intending planters. December to March. 


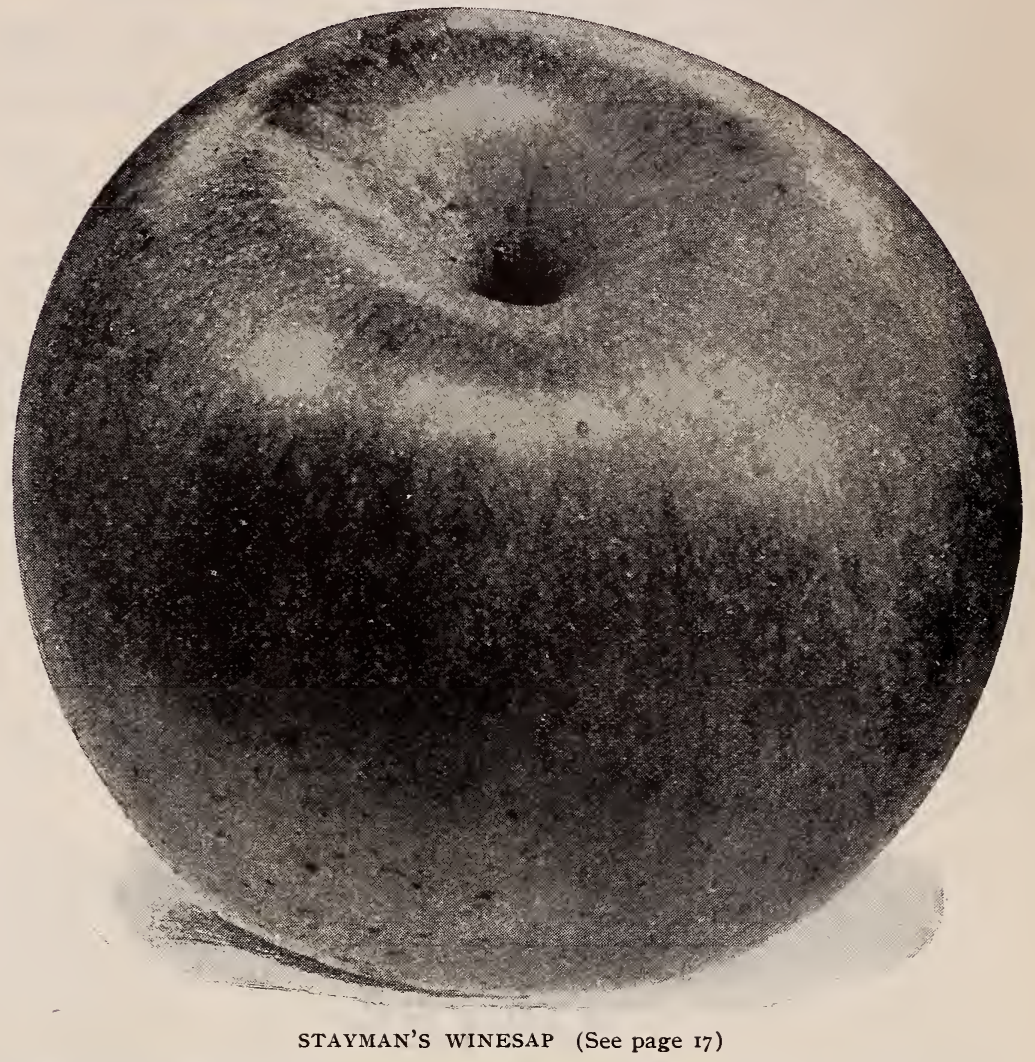

Albemarle Pippin. Perhaps no Apple stands higher in the market than this, or brings as high a price; others may be more profitable to the grower. It needs a deep, warm soil to bring it to perfection. Where it does well, we would still advise planting it largely for market. Fruit large, round, lop-sided, ribbed and irregular; surface smooth, yellowish green, sometimes bronzy, becoming yellow when ripe; flesh yellow, firm, brittle, juicy; flavor acid, rich. agreeable; tree a slow grower in the nursery; does not succeed so well below the Piedmont country. January to April.

Baldwin. An old favorite. Large ; deep red; very juicy, and of good flavor ; a very heavy bearer and good keeper. November to March.

Delaware Winter (Lawver). Of medium to large size ; bright red; the flesh is of fine grain, crisp and subacid; the tree is a vigorous grower and very productive. An early Apple, and a great favorite. October to December.

Duchess of Oldenburg. A Russian variety of medium size; of good shape, and beautifully striped with red; fine quality. Early September.

Early Harvest. One of the earliest of Apples. Of medium size and bright golden color; subacid and tender. July and August.

Early Ripe. This fine Apple, coming as it does immediately after the Early Harvest, fills a want long felt by the orchardist. Its large size, handsome appearance and good bearing qualities combine to make it the most profitable market variety of its season; the tree is hardy and of vigorous growth; fruit large, yellowish white ; flesh white, juicy, subacid ; fine for table or for cooking. First of July.

Early Strawberry. Medium size, with tender flesh of a fine, mild flavor; beautifully marked all over with red. August.

Early Sweet Bough. A very early and prolific sweet Apple of large size and oblong shape; pale greenish yellow, and of delicious flavor; tree a moderaie grower. July and August. 


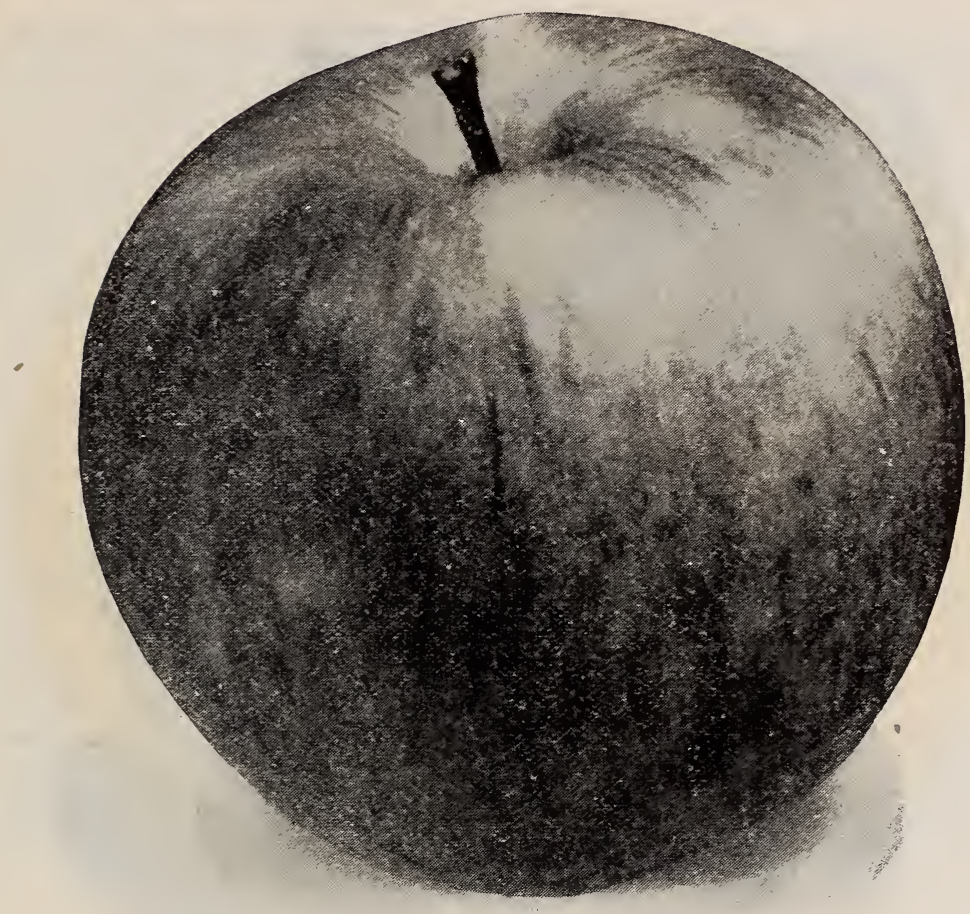

JONATHAN APPLE

Fallawater. A good winter Apple; very large, almost round, and of regular shape ; skin smooth, of a yellowish green, with dull red cheek; flesh greenish white, fine-grained. A good, profitable variety for the orchard, as it is very prolific. Keeps till March.

Fall Pippin. Very large, roundish; skin smooth, yellowish green, becoming rich yellow when ripe; flesh yellowish, firm, becoming tender, rich, aromatic, excellent; valuable for cooking and market; succeeds well everywhere, and is a great favorite. September to December.

Fourth of July. Valuable for cooking and market; fruit medium, roundish oblate, conical, slightly ribbed; whitish yellow, striped and splashed with bright red; it has been thoroughly tested and found to be one of the very best early Apples. Matures early in July.

Gano. Large, of perfect form, and very smooth; red, shaded deep on sunny side. A splendid shipper and keeper. The tree is strong, healthy and perfectly hardy ; an early and prolific bearer. February to May.

Gravenstein. Large, roundish ; striped with red ; flesh tender, juicy, very rich, subacid, high flavored; productive, handsome and good ; fine in all localities. August.

Grime's Golden. Of high quality. A bright yellow Apple, which grows and bears well in every section of the country; very productive. January to April.

Jonathan. Medium size, nearly covered with brilliant stripes of clear red on a pale yellow ground; flesh white, very juicy, spicy, subacid, moderately rich. Keeps well through winter. Tree very productive. Succeeds well in most localities.

King of Tompkins County. A very king among Apples; of the largest size, and most beautiful shade of red, striped with crimson; excellent quality and flavor. The tree is a hardy, vigorous grower and an abundant bearer. December to March.

Lankford's Seedling. Large size ; red, striped with darker shade ; particularly valuable for southern growing. Tree is a splendid bearer, with fruit of excellent keeping qualities. This Apple has been kept until May and Iune with ordinary treatment. 


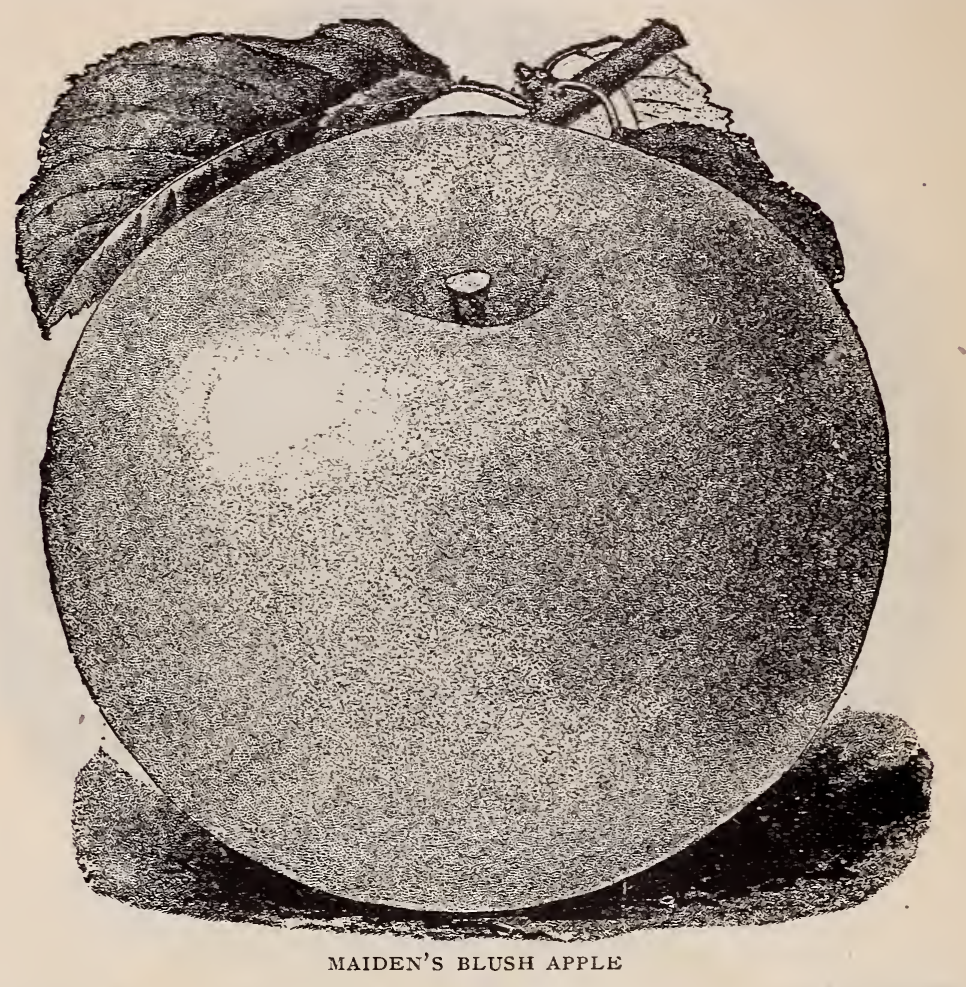

Limber Twig. A southern Apple of great popularity. Medium size, with a rich aromatic flavor; in color is of a dark, purplish red, and is borne in great profusion upon the very thrifty trees. January to April.

Maiden's Blush. A very beautiful Apple, native of New Jersey. A most valuable variety for the table, as its brilliant color makes it a decided ornament. Particularly good also for drying. A handsome, rapid-growing tree, with a fine, spreading head; very prolific. Fruit of medium size and regular shape, with smooth skin; pale lemon-yellow, with a brilliant crimson cheek. September and October.

Northern Spy. Large, conical, flattened; striped and quite covered on the sunny side with dark crimson and delicately coated with bloom; flesh white, finegrained, tender, slightly subacid; both leaf and blossom buds open a week later than most other sorts. An Apple of very high character, but we cannot advise its planting south of Pennsylvania, except in mountain regions. November to February.

Pewaukee. Medium to large; bright yellow, partly shaded with dark red. Very much like Duchess of Oldenburg, of which it is a seedling. Flesh yellowish white ; tree hardy and vigorous. January to June.

Rambo, Summer. One of the oldest varieties of French origin, and at one time was one of the most profitable for early marketing. The tree is hardy, growing with an open, round head. Fruit is above medium size and rather flat, of a pale greenish yellow, streaked and splashed with red on sunny side ; flesh rather soft and sprightly subacid. Early September.

Rambo, Winter. This is one of the most popular autumn or early winter Apples, and a universal favorite wherever grown. It is a fruit equally valuable for dessert or cooking, and the tree thrives well on sandy soil, being very vigorous, spreading in habit, and very prolific. The fruit is of medium size, flat and smooth; yellowish white, streaked with yellow and red on the sunny side, occasionally marked with large rough dots. Flesh is greenish white, tender, rich and subacid. October to December. 
Rawle's Janet, or Jenneting (Never-Fail in the South). A Virginian variety, from the farm of Caleb Rawle, in Amherst county. The tree is very vigorous and spreading, coming into leaf and blossom later than most varieties, thereby avoiding injury by late frosts. Much cultivated in the South and Southwest. Fruit is large and conical in shape. Yellow, shaded with red, with darker stripes. February to June.

Red Astrachan. One of the handsomest Apples grown, with a bloom on its smooth, waxy surface much like that on a plum. The tree is an abundant bearer and vigorous in growth, upright and spreading. It is a magnificent dessert fruit, but apt to get mealy if allowed to remain on the tree after ripening. Rather large, smooth and round. Of a beautiful shade of red, occasionally running into a greenish yellow in the shade. Flesh is white, crisp and juicy, with a rich acid flavor. July and August.

Rome Beauty. A splendid Apple, thriving well in the Southwest. The tree is a moderate grower and late bloomer. Fruit is large and round, somewhat conical; yellow, striped with red; flesh yellowish, tender and juicy. October to December.

Smith's Cider. A valuable Pennsylvania variety, and much esteemed as a profitable market sort. Tree very vigorous and productive. Fruit is medium to large, irregular in shape; yellowish, striped red and slightly dotted with gray. Flesh is white, tender, juicy, crisp and pleasant.

Smokehouse. Another Pennsylvania variety, where it is very popular and well known. Tree is moderately vigorous, with spreading head, and extremely productive. Fruit is large and roundish, with yellow skin, shaded and splashed with crimson, and thinly sprinkled with large gray and brown dots. Flesh yellowish, firm, juicy and crisp. One of the best cooking Apples grown, and deserves even wider cultivation. September to February.

Stark. A very valuable Apple for southern planting on account of its large size, fine appearance and fine keeping qualities. The tree is vigorous, upright and spreading. Fruit large, round and somewhat conical ; greenish yellow, shaded, splashed and striped with red over almost the entire surface. Flesh yellowish, juicy and mildly subacid. January to May.

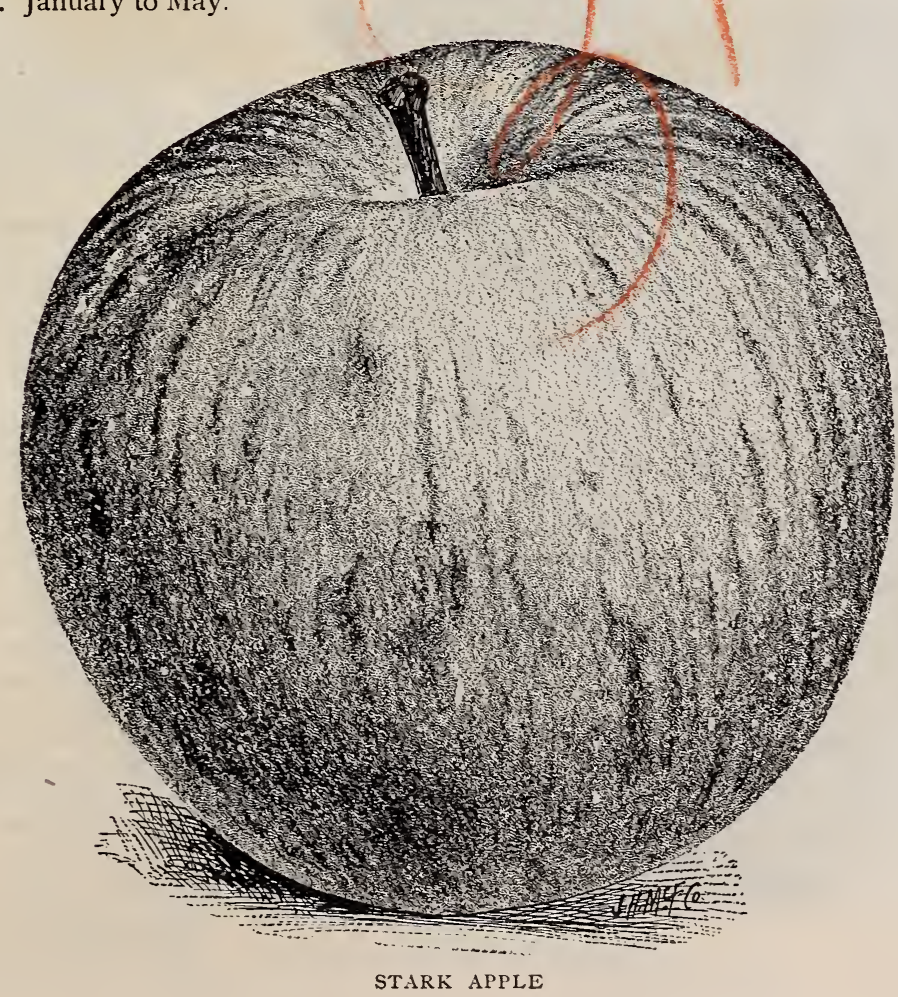


Twenty-Ounce. An old favorite, with various names. Very large and showy, and on account of these qualities a valuable fruit for market. Fruit is round and slightly uneven, of a greenish yellow, splashed and marbled with purplish red; very productive. October to January.

Winesap. One of the finest cider Apples grown, both in its over-abundance of juice and its productiveness. The tree grows irregularly, but it bears early, and the fruit has the good quality of hanging late upon the tree without injury. Fruit is of medium size, and oblong, with a smooth skin of a fine dark red, with a few streaks. Flesh yellow, firm and crisp, and of high flavor, with the peculiar snap which makes it a favorite variety for eating. The tree is compact and vigorous and a good bearer. Winesap is a very valuable Apple, and we are glad to call attention to our fine stock of it. November to May.

Yellow Transparent. One of the earliest yellow Apples grown. Very valuable on that account, as it is ready for market ten days ahead of Early Harvest. Above medium size, beautiful in appearance, with firm flesh and crisp, subacid flavor. Tree vigorous, thrifty and a good bearer. July.

York Imperial. (Johnson's Fine Winter.) One of the finest Apples in existence; of medium size, shaded with crimson on sunny side, thinly sprinkled with gray dots. Flesh yellowish, firm, crisp, juicy and mildly subacid. A splendid keeper, and equally valuable for the table or for cooking. Tree is vigorous and very productive.

\section{CRAB APPLES}

All the leading varieties, such as Hewes' Virginia, Hyslop, Red Siberian and Yellow Siberian. 35 cts. each, $\$ 25$ per Ioo.

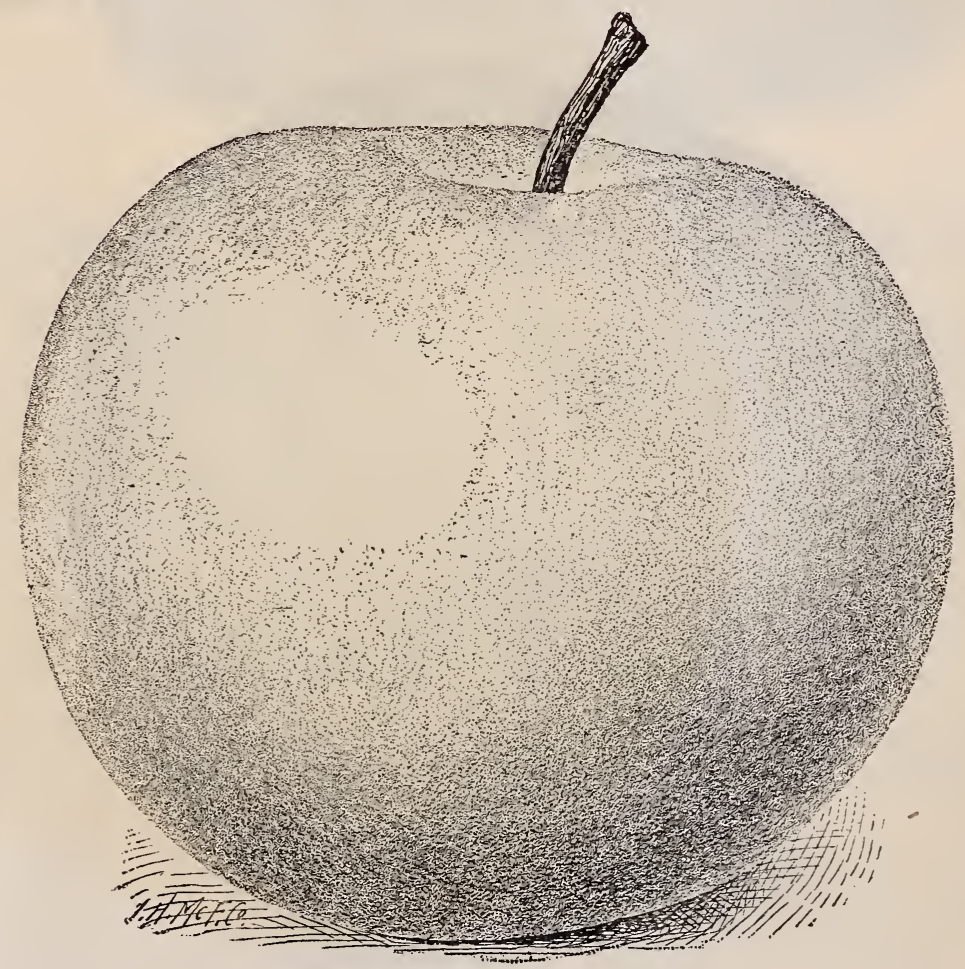

YELLOW TRANSPARENT APPLE, 


\section{PEARS}

Our stock of Pear trees, both sta ndard and dwarf, is particularly strong, hardy and true to name. We exercise great care in the packing and, if proper care is taken, our stock will grow and bear with great success.

Standards of two or three years' growth are from $4 \frac{1}{2}$ to 7 feet high. Dwarfs of two years average $21 / 2$ to 4 feet. These are the most suitable sizes for safe transporting and planting. Plant standards not less than 20 feet apart. Dwarfs will do as well at 8 to ro feet, and may be advantageously used to occupy the spaces between the standards. They have the further recommendation of being earlier than standards.

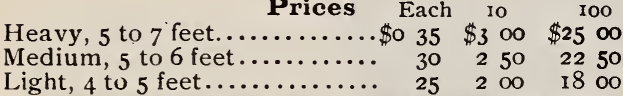

These prices apply to all but those specially noted

\section{STANDARD PEARS}

Anjou (Beurre d'Anjou.) (Winter). Many consider this as the best pear grown. A splendid keeper, often being in prime condition in midwinter, when it commands the highest prices.

Angouleme(Duchesse d'Angouleme). (Autumn.) Very large ; of a dull greenish yellow; very juicy and sweet.

Bartlett. (Summer.) The old standard variety, of which the people never grow tired. Its large size and rich musky flavor make it a universal favorite. Tree bears young, and is very prolific, being strong and robust.

\section{Clapp's Favorite.} (Summer.) Very large and desirable, ripening just before Bartlett. Should be picked early, or there is danger of its rotting on the tree.

Comet (Lawson of some). (Summer.) One of the largest early Pears, and particularly free from blight ; a young and abundant bearer. Yellow, with crimson blush next to the sun.

Garber. (Autumn.) Very much like Kieffer in shape and size but is two or three weeks earlier. Bright yellow, with faint blush. Tender, sweet and juicy. Imme ns ely productive and bears when very young.
April 28, 1905

Dear Sir:-The trees arrived in good shape and are satisfactory. Feel like complimenting you on being able to grade them so perfectly. Out of the 200 only two varied a little, all presenting an even appearance.-JOHN ADAMS Ransomville, N. Y. 
Howell. (Autumn.) A large Pear, obtuse pyriform in shape; yellow, with red cheek ; rich, juicy, sweet.

Idaho. (Autumn.) One of the late sorts, of very large size and round in shape ; yellow, with bronze cheek; flesh rich, melting and vinous; hardy, vigorous and productive.

Koonce. (Summer.) Very early, and similar in shape, size and color to Comet, but much better ; free from blight ; very productive and a strong, handsome grower. A popular variety.

Lawrence. (Winter.) Not so large, but of fine quality ; flesh juicy and melting, and with exquisite perfume. One of the best early winter sorts.

Lawson. See Comet.

Le Conte. (Summer.) A beautiful, smooth, yellow Pear, ripening about two weeks ahead of Bartlett ; a splendid shipper and free from blight ; a very prolific sort.

Manning's Elizabeth. (Summer.) This pretty little Pear makes a splendid ornament for the table; rich red and yellow in color; small in size and borne in clusters.

Seckel. (Autumn.) This name has grown to be almost synonymous with Pear, as it is undoubtedly the best known fruit of that kind in existence. Snall, but of the

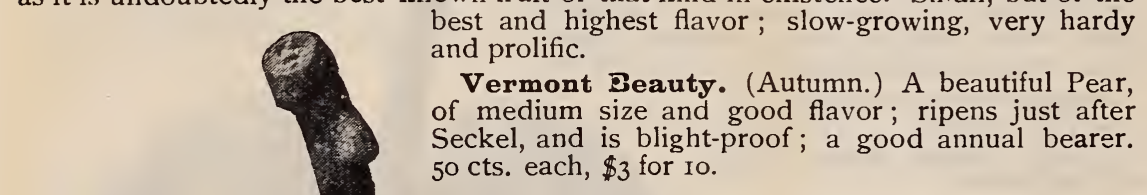

\section{DWARF PEARS}

All our Dwarf Pears are set on quince stock, and come into bearing sooner than the standards. Strict attention to them and high cultivation will result in magnificent yields of fruit. The size of the trees makes them valuable on account of the ease of collecting the fruit. Two to three years old 25 cts. each, $\$ 2$ for Io, $\$ 15$ per Ioo.

We have on hand good, thrifty trees of the following varieties, descriptions of which will be found under Standard Pears.

\section{Anjou. Angouleme. Howell. Lawrence. Manning's Eliza. beth. \\ Seckel.} Geary's Hold-On) arrived in good order and I was pleased with them. I enclose you post-office order for \$2.70 to pay enclosed bill-with my thanks for the same and the low price charged for same. With my regards and wishing you much success. Yours truly. - JNo. P. FORT, Athens, Ga. 


\section{The Great Kieffer Pear}

Of all the Pears grown for commercial purposes the Kieffer is indisputably the leader, as it combines with its appearance, flavor and tenderness, a size which makes it extremely profitable, specimens having been known to exceed four pounds in weight. The trees commence to bear the second year after transplanting, and are apt to over-bear. Thinning the young fruit is very beneficial, and results in a greatly increased yield in size and weight of the crop from each tree. It has been rightly called "The Business Man's Pear," as it has resulted in more business and profit to the grower than any other variety known.

The Kieffer Pear is a seedling of the Chinese Sand Pear, supposed to have been crossed with Bartlett. The fruit, as noted above, is larger than any other variety, with a bright yellow skin beautifully suff u sed with red on the sunny side. Its flesh is tender, brittle, sweet, very juicy and with a marked musky aroma.

The Kieffer Pear has never had its merits fully realized, as it has, as a rule, been sent to market in an immature condition and before it

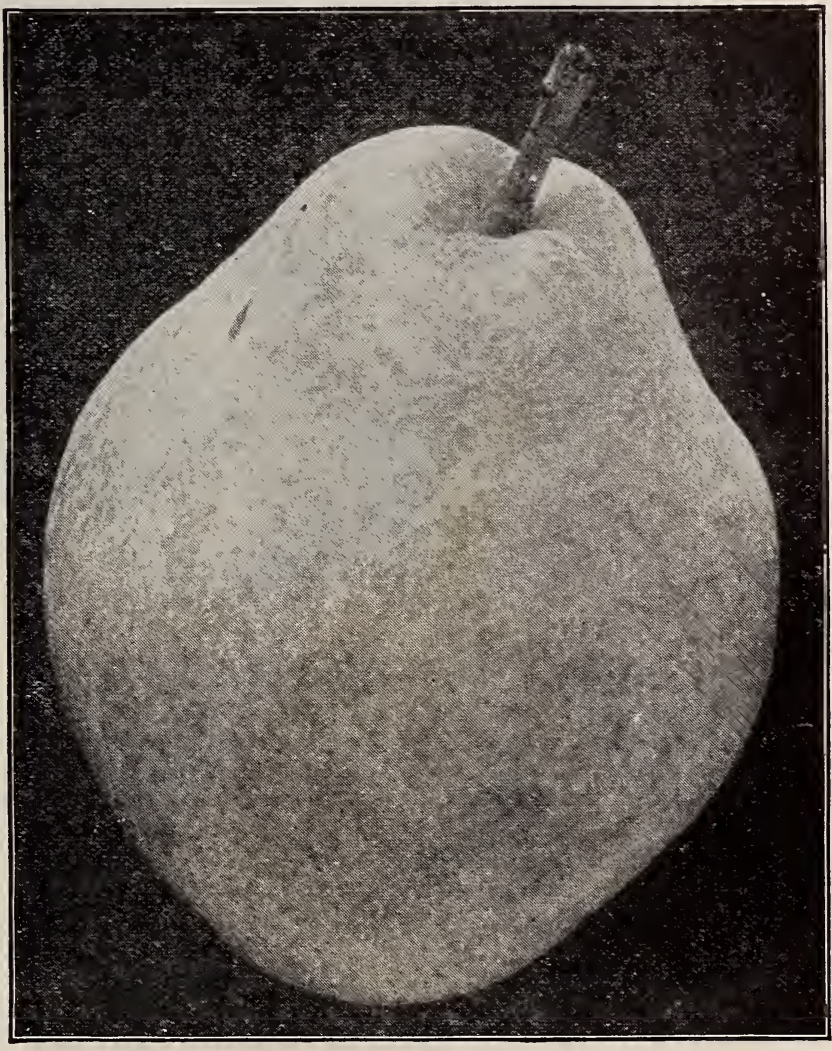

KIEFFER PEAR

has attained its full

size. On that account it has been misjudyed and there are many today who, while they think they know the Kieffer, have no idea of its good qualities. The only proper way to treat it is to allow it to hang upon the tree until the beginning of October and then ripen it in a cool dark room. With this care taken of it, it becomes tender, juicy and rich, and the peculiar perfume of the Bartlett is a distinguishing feature of it.

In planting the Kieffer, the best results are obtained by planting some other variety with it for the purpose of pollenizing its blossoms. LeConte, Garber and Bartlett, in the order named, are all good for this purpose, as they blossom at the same time. In our own orchards Bartlett has given good results, and our Kieffer Pears grown next to Bartletts have shown a marked improvement in quality and flavor.

We have a particularly fine lot of Kieffer Pear trees, all first-class, which we list at the following prices:

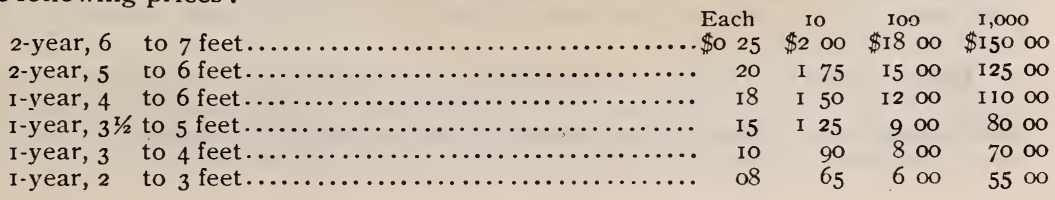




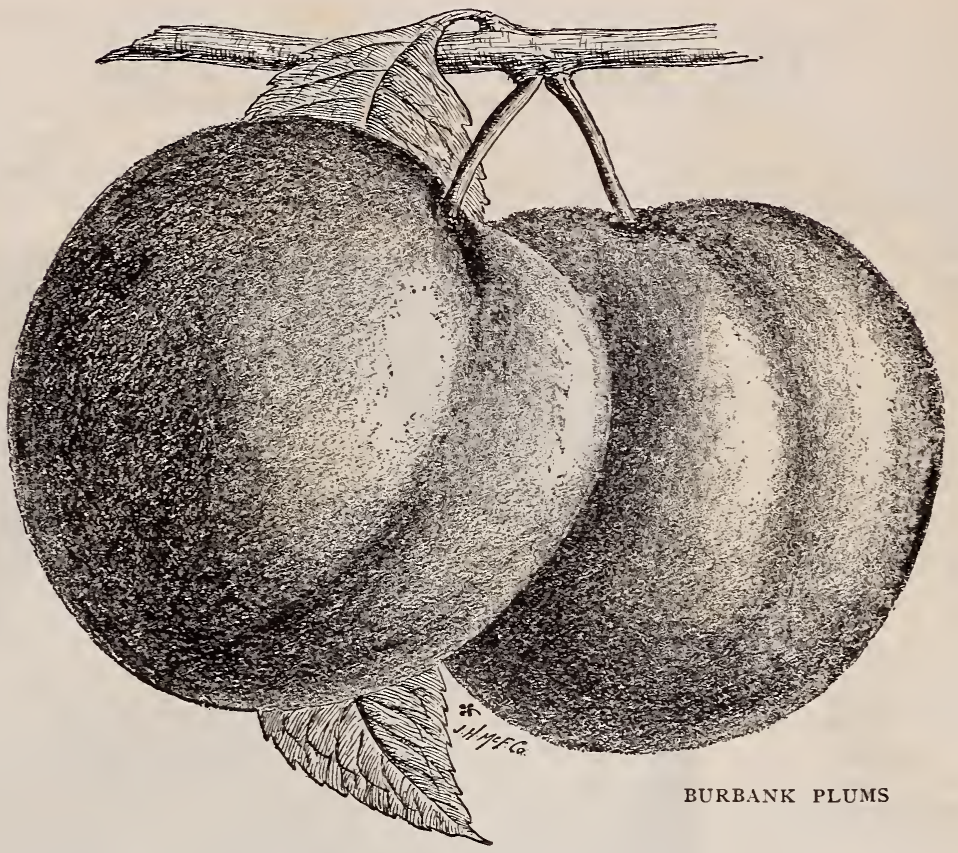

\section{PLUMS}

Plums have always been considered hard to raise in this section of the country, but since the introduction of the Japanese varieties, they are as easy to grow as peaches, requiring about the same general treatment. Our Plums are worked on plum roots.

\section{Prices of Plum Trees on Plum Roots:}

Each io Ioo

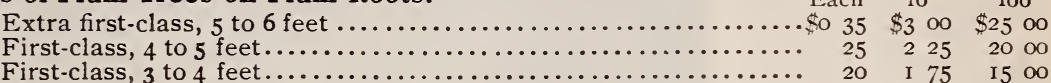

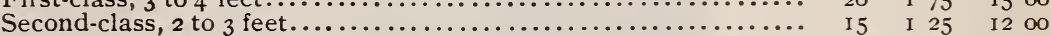

\section{JAPANESE PLUMS}

Abundance (Botan of some growers). Of medium size, round, with slight point; beautiful shade of red over yellow body; flesh yellow, firm and juicy, with a slightly subacid flavor; skin is rather tough, making it a good shipper ; clingstone ; very prolific. Ripens early in July.

Burbank. A beautiful, large Plum of roundish conical form, with blunt point; ground color orange, thinly overlaid with red, and showing many orange dots ; flesh firm and meaty, yellow, rich and sugary. One of the standard varieties, and a most valuable one. Ripens from middle of July to first of August. A good shipper.

Climax. Beautiful heart-shaped fruit, very highly colored, of delicious flavor and exceedingly fragrant. One of the earliest Plums to ripen, and very productive. Tree is an extremely vigorous upright grower, with strong branches and large leaves.

Chabot. Medium to large and oblong conical in shape ; of a beautiful light red, with many bright golden dots; very productive; an excellent variety for drying. Ripens early in September.

Hale. One of the most satisfactory Plums in cultivation, and rapidly growing in popular favor. Large in size and round ; of beautiful golden orange, thinly overlaid with mottled red, giving it a yellowish red appearance; flesh yellow, soft and juicy; flavor delicious; a splendid keeper and shipper; clingstone. Ripens very late. 


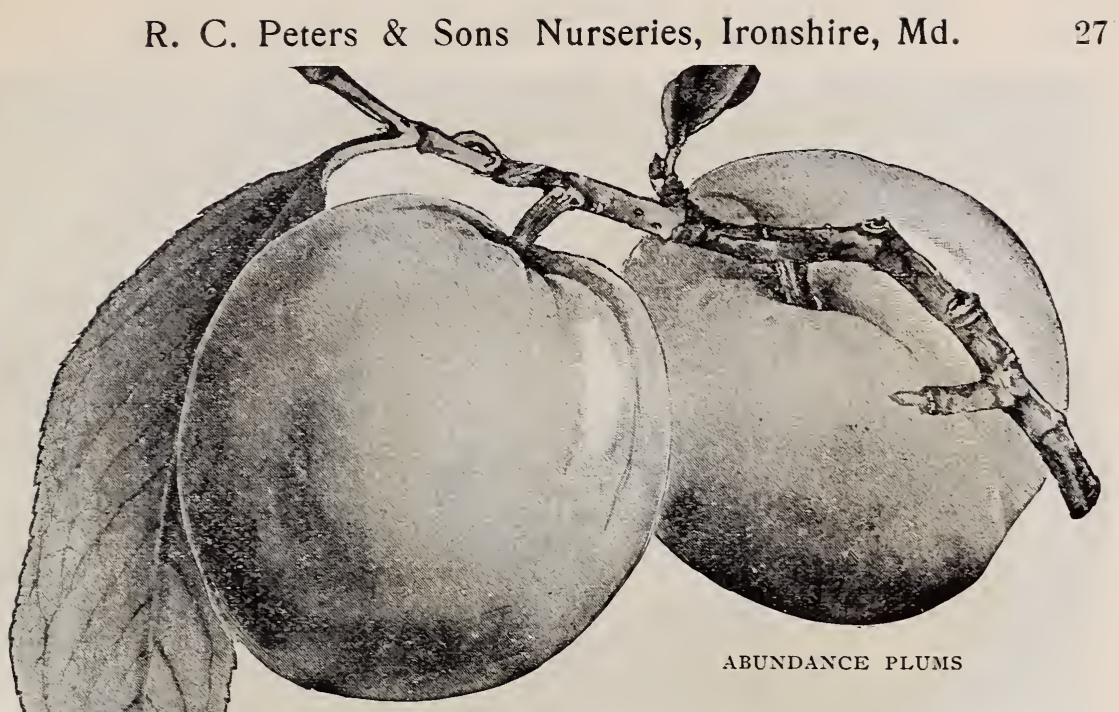

Kelsey. Very large, heart-shaped, with deep suture; somewhat lop-sided. Of a rich, royal purple, on yellow ground, beautifully dotted; flesh light yellow and firm, with rich, pleasant flavor; freestone.

Ogon. Medium in size, rather flat on ends; lemon-yellow, with creamy bloom; flesh thick and very meaty; freestone. A splendid keeper and shipper. A good canning variety, ripening about August r.

Red June. Medium to large in size, decidedly conical, with deep suture; of a beautiful, deep vermilion-red, with handsome bloom; flesh light yellow, firm and rather juicy, sprightly subacid; half cling, with small pit. Ripens ahead of Abundance.

Satsuma. A very large, beautiful, dark red Plum, with blood-red flesh, rather coarse in quality, but very firm and of good flavor; freestone. One of the best keepers, and an exceedingly valuable sort, ripening late in the season.

Shropshire Damson. A great improvement over the old Damson, it being the largest of its class; of a rich, dark purple. Particularly valuable for preserving. Tree is very vigorous and enormously productive. September.

Wickson. Remarkably handsome, very large and of a deep maroon-red; one of the hardiest ; flesh amber-colored, firm, meaty and clinging to the pit, which is small. One of the most desirable Plums, either for home use or for market.

Wild Goose. Of medium size, oblong, and of a bright vermilion ; very juicy and sweet; a clingstone, but of excellent quality and very productive. Nearly proof against the curculio. One of the most profitable varieties, especially in the South. July.

Willard. One of the earliest Plums, of medium size and rather oblong in shape. Of a beautiful claret-red, covered with minute golden dots. The tree is particularly strong, vigorous, hardy and productive. Will keep two or three weeks after picking. A good shipper and valuable market variety. Special prices, on plum roots only.

\section{QUINCES}

Plant to to I 2 feet apart each way. Under favorable conditions this is a most profitable fruit. Heavy manuring, clean cutting and judicious spraying will all tend to the production of heavy, perfect crops.

First size...... Each Io Ioo

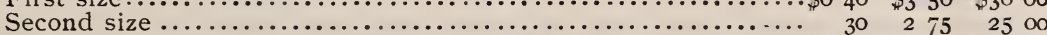

Champion. Very large, showy, and free from lumps. Tree a heavy hearer, strong and vigorous. Late.

Meech's Prolific. Medium size ; tender, smooth, bright yellow ; very productive; a variety which is coming into great favor.

Orange, or Apple. Large and round, and of a bright yellow. One of the best known and most widely cultivated. Late. 


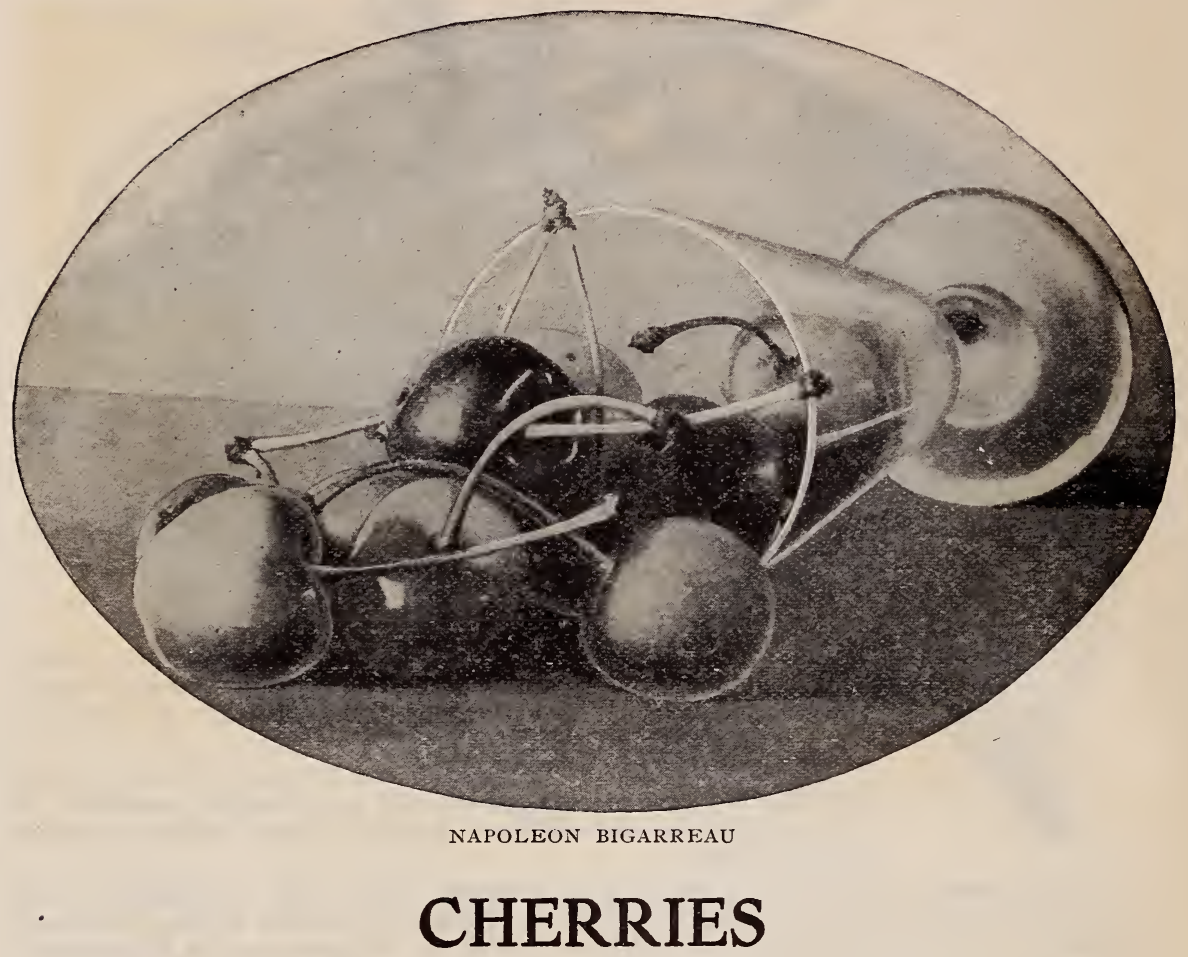

The Cherry succeeds on most soils and in nearly all localities throughout this country, but attains its greatest perfection upon those of a light, gravelly or sandy nature, provided they are in good condition. In planting Hearts and Bigarreaus, avoid wet or damp situations. The Dukes and Morellos will bear more moisture, but will flourish best in a soil that grows the others to the greatest perfection.

Prices, except where noted:

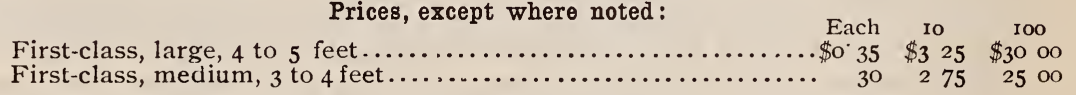

\section{HEART AND BIGARREAU CHERRIES}

Bigarreau, or Graffiors (Yellow Spanish). Very large; pale yellow, with red cheek; flesh firm, with a fine, rich fiavor. July.

Black Tartarian. Fruit of the largest size; flesh dark, half-tender, rich, nearly destitute of acid, fine flavor. A general favorite. June.

Coe's Transparent. Medium size; pale amber, reddened in the sun; flesh tender, melting and juicy, with a delicate flavor; very productive. Beginning of June.

Downer's Late Red. Medium size ; light red, amber in the shade; flesh tender, with a very high, sweet flavor. A good late sort. July.

Elton. One of the finest Cherries; fruit large, pale yellow, blotched red; flesh firm, becoming tender, juicy, rich and highly flavored; very productive. May and June.

Governor Wood. Fruit large; skin yellow, shaded red; flesh nearly tender, iuicy, rich; tree vigorous. June.

Napoleon Bigarreau. Is one of the best of the firm-fleshed Cherries; of the largest size ; well-flavored; skin yellow, dotted red: flesh firm, juicy, good flavor; profitable for marketing. June 


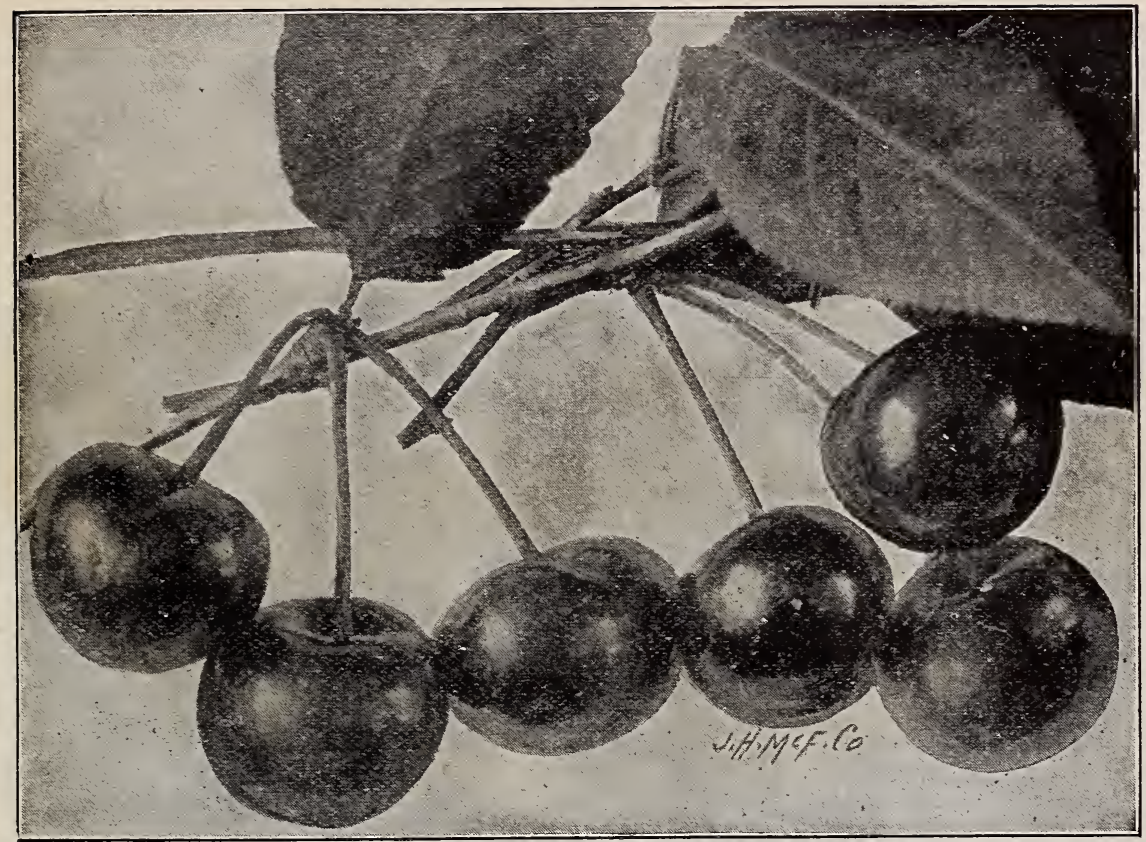

EARLY RICHMOND

Rockport Bigarreau. Large ; deep red; flesh rather firm, juicy, sweet, rich , excellent flavor ; a very desirable and profitable Cherry. Beginning of June.

Windsor. Origin Canada ; fruit large, liver-colored ; flesh firm and of fine qual ity ; tree very hardy ; a valuable late variety. July.

\section{DUKE AND MORELLO CHERRIES}

The Dukes and Morellos are not so upright in their growth as the Hearts and Bigarreaus, forming low, spreading heads. The fruit is acid or subacid.

Dyehouse. Resembles Early Richmond, but is of finer quality and several days earlier; fruit medium; skin bright red, darkened in the sun ; flesh soft, juicy, tender, sprightly subacid, rather rich in flavor.

Early Richmond. Medium size ; red ; flesh melting, juicy, and at maturity of a rich acid flaver; very productive; fine for cooking. Commence ripening in May; hangs long on the tree.

Empress Eugenie. Large, roundish, flattened; rich dark red, with pink flesh; tender, juicy, rich with small stone.

Late Duke. Large, light red ; late and one of the finest. Tree is a strong, upright grower.

May Duke. Medium size ; dark red; melting, rich, juicy ; old and popular sort.

Montmorency, Large-fruited. Fruit large, and the finest flavored in this class ; free grower, hardy and prolific.

Olivet. Of the Duke class. Large, globular, very shining, deep red ; flesh red, with rose-colored juice; tender, rich, sweet, subacid flavor. It ripens in May or early in June. It possesses the fertility of the Duke tribe, and is perhaps the largest of that class.

Wragg. Much like English Morello, but larger, better and hardier. Nearly black in color, tender and juicy. Tree vigorous and heavy bearer. 


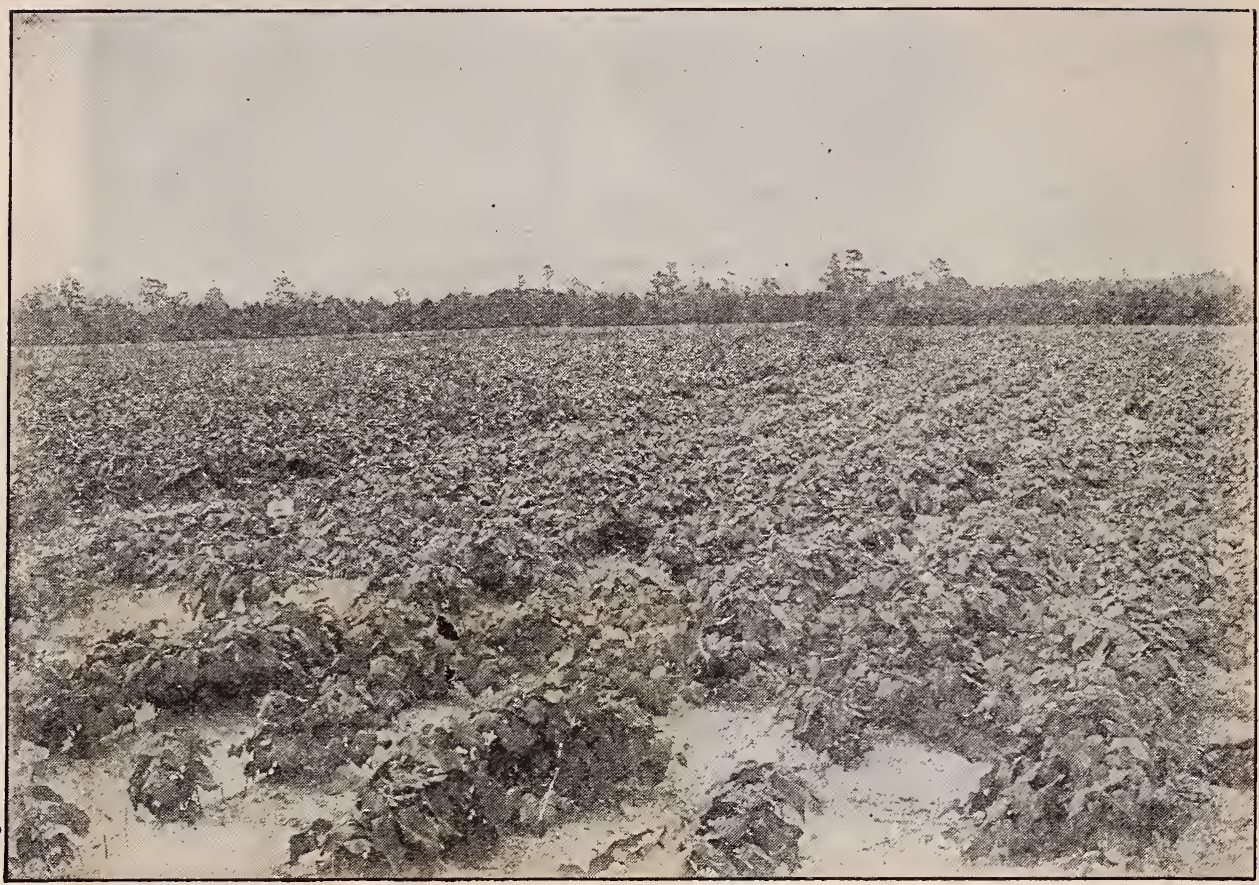

GRAPE NURSERY

One-year vines from cuttings. Represents planting of over one million. Taken in July at Nurseries of R. C. Peters \& Sons, Ironshire, Maryland.

\section{GRAPES}

The Grape is the most satisfactory of all fruits to raise, as it can be put to so many different uses. It can be confined to a stake, bound to a trellis, trained over an arbor, or to cover a large building, and under all conditions will yield its delicious fruit. No fruit will give better returns for close attention and kind care, and good returns can be had from soils which are unfit for any other crop. The side of a hill freely exposed to the sun and air is an ideal place for grape culture, whether the soil be sandy, clayey or loamy. Careful pruning is necessary for good crops, and should be done when the vine is entirely dormant. Thinning out the young branches will more than pay the cost by the increased size and quality of the fruit allowed to mature. All our vines are strong, vigorous, 2-year-old stock, and guaranteer to give perfect satisfaction.

We make a specialty of growing Grape-vines for commercial planting, and are in a position to supply vineyards, no matter how large. Concord, Moore's Early and Niagara are our leading specialties, and of these three varieties we can supply any quantity. Our land is well adapted to the propagation of the Grape, and our vines have plenty of strong, fibrous roots, which insure their strong and quick growth.

\section{BLACK GRAPES}

Champion, or Talman. A large Grape, clear of rot, and very prolific ; early. Io cts. each, 50 cts. per doz., $\$ 3$ per Ioo, $\$ 20$ per I,000; 2-year vines, $\$ 30$ per I, 000. 
CONCORD. One of the most popular and reliable varieties we possess. The standard in many localities, and very productive. Ripens in mid-season. Bunch large, compact and shouldered; berry large, round, almost black with blue bloom; juicy, buttery and very sweet. Recognized everywhere as the standard market Grape. Io cts. each, 50 cts. per doz., $\$ 2$ per IOO, $\$$ Io per I,000; 2-year vines, $\$ 25$ per I,000. Special prices for larger quantities.

Eaton. A seedling of Concord. Splendid large, round, black berry in largeshouldered bunch. Very juicy and tender. I5 cts. each, $\$$ r.25 per doz., $\$$ Io per Ioo.

McPike. One of the finest black Grapes. Large, compact bunch, with the berries of even size. Stock is limited. I-year vines, 50 cts. each.

MOORE'S EARLY. Bunch large, berry large, round, with heavy blue bloom ; vine exceedingly hardy. Its earliness makes it desirable for an early market; its hardiness particularly adapts it to Canada and northern portions of the United States ; succeeds admirably in the South. Io cts. each, $75 \mathrm{cts}$. per doz., $\$ 4$ per 1oo, $\$ 20$ per I,000; 2-year vines, $\$ 30$ per 1,000 . Special prices for larger quantities.

Worden. An improved Concord, and a little earlier. One of the best blacks. ıo cts. each, 75 cts. per doz., $\$ 4$ per Ioo, $\$ 35$ per I, ooo.

\section{RED GRAPES}

Agawam (Rogers' No. I5). Very large; skin thick; sweet and early. Io cts. each, $\$$ I per doz., $\$ 4$ per Ioo, $\$ 25$ per I, 000; 2-year vines, \$30 per I,000.

Delaware. Small, but exceedingly fine. A leading early market Grape. I5 cts. each, \$I per doz., $\$ 5$ per IOo, $\$ 40$ per I, ooo.

Wyoming Red. Double the size of Delaware; vines strong; early. ro cts. each, 75 cts. per doz., $\$ 4$ per IOo, $\$ 35$ per I,000.

\section{WHITE GRAPES}

Empire State. Bunch large and shouldered; yellowish white: rich, sweet, sprightly. An all-round good early Grape. I5 cts. each, \$1.25 per doz., \$Io per Ioo.

Lady. One of the best white Grapes. Extra-early ; very hardy and prolific. ro $\mathrm{cts}$. each, $75 \mathrm{cts}$. per doz., $\$ 4$ per Ioo.

Martha. A seedling of the Concord; white; very reliable. Ioc. each, 75 cts. per doz., $\$ 4$ per Ioo.

NIAGARA. Occupies the same position among the white varieties

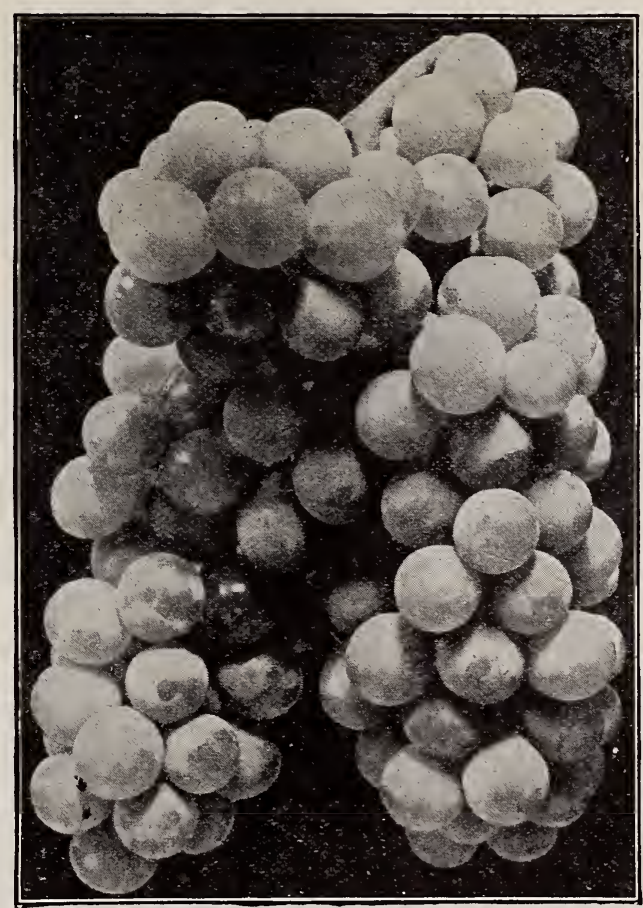

MOORE'S EARLY as Concord among the black; the leading profitable market sort. Bunch and berries large, greenish white, changing to pale yellow when fully ripe. Skin thin but tough; quality much like Concord. Its color and quality make it a particularly valuable variety for the table. Io cts. each, 75 cts. per do $z$., $\$ 4$ per I00, $\$ 25$ per I, o0o; 2 -year vines, $\$ 30$ per 1,000 . Special prices for larger quantities.

Pocklington. Largest and most showy white; a standard of its class. Very hardy and prolific; medium. Io cts. each, 75 cts. per doz., $\$ 4$ per Ioo, $\$ 35$ per I, oc.

We can furnish any other variety, if desired. Prices upon application. 


\section{DECIDUOUS TREES}

In our Deciduous Tree department we devote our attention exclusively to raising Norway Maples, considering these absolutely the best shade tree grown, although we

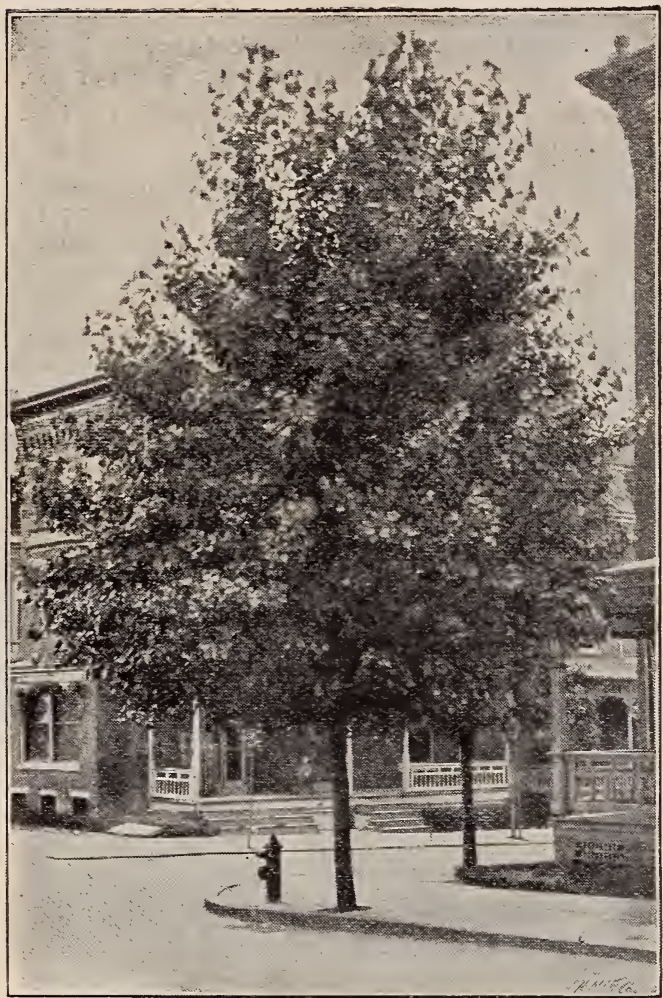

CAROLINA POPLAR can supply almost every other shade and ornamental tree, either evergreen or deciduous, sent out by other nurseries, and will furnish prices upon application.

\section{Prices of Norway Maples:}

Extra heavy, i2 to I4 feet, $\$ 1$ each, $\$ 9$ for Io, $\$ 80$ per Ioo.

First-class, to to 12 feet, $75 \mathrm{c}$. each, $\$ 7$ for 10, $\$ 65$ per 100 .

First-class, 8 to 9 feet, 50 cts. each, $\$ 4.50$ for $10, \$ 40$ per 100 .

First-class, 6 to 8 feet, $40 \mathrm{cts}$. each, $\$ 3.50$ for Io, $\$ 3$ o per Ioo.

\section{Prices of Carolina Poplar :}

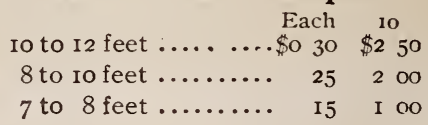

\section{EVERGREENS}

Rosedale Hybrid. 2 to 3 feet, $\$$ r each, $\$ 8$ for Io. Other varieties furnished on application.

\section{CALIFORNIA PRIVET}

Of all ornamental hedge plants, this is the most highly prized. If cut to the ground one or two years after planting, it makes a very thick hedge right from the bottom, sending up many strong shoots. The leaves are a rich green, and will remain on the plants up to Christmas, and if they are a little sheltered they will keep green almost all winter. This is especially the case if the hedge has attained some age and has frequently been trimmed. Though it is a strong grower, it can be kept to a low size by frequent trimming. At Newport, R. I., there are a great many hedges of this plant that are 6 and 7 feet in height, which have been trimmed flat on the sides, so that they look like a solid green wall. It seems to thrive particularly well near the seacoast. Drought does not seem to injure it in any way. Our stock of California Privet is particularly fine, and is in proper condition for transplanting. In forming a hedge set the plants deep, 8 to ro inches apart, and trim back very close.

\section{Prices:}

Per $100 \quad 1,000$

3-year-old plants, extra heavy, well branched, 4 to $4^{1 / 2}$ feet.........\$6 $00 \$ 500$ 2-year-old plants, first-class, well branched, 3 to 4 feet............. 4 oo 35 oo 2-year-old plants, first-class, well branched, $2 \frac{1}{2}$ to 3 feet...................... 350 I-year-old plants, first-class, well branched, 2 to 3 feet............. 3 oo 2500 I-year-old plants, second-class, not branched, I to 2 feet........... $250 \quad 20$ oo 


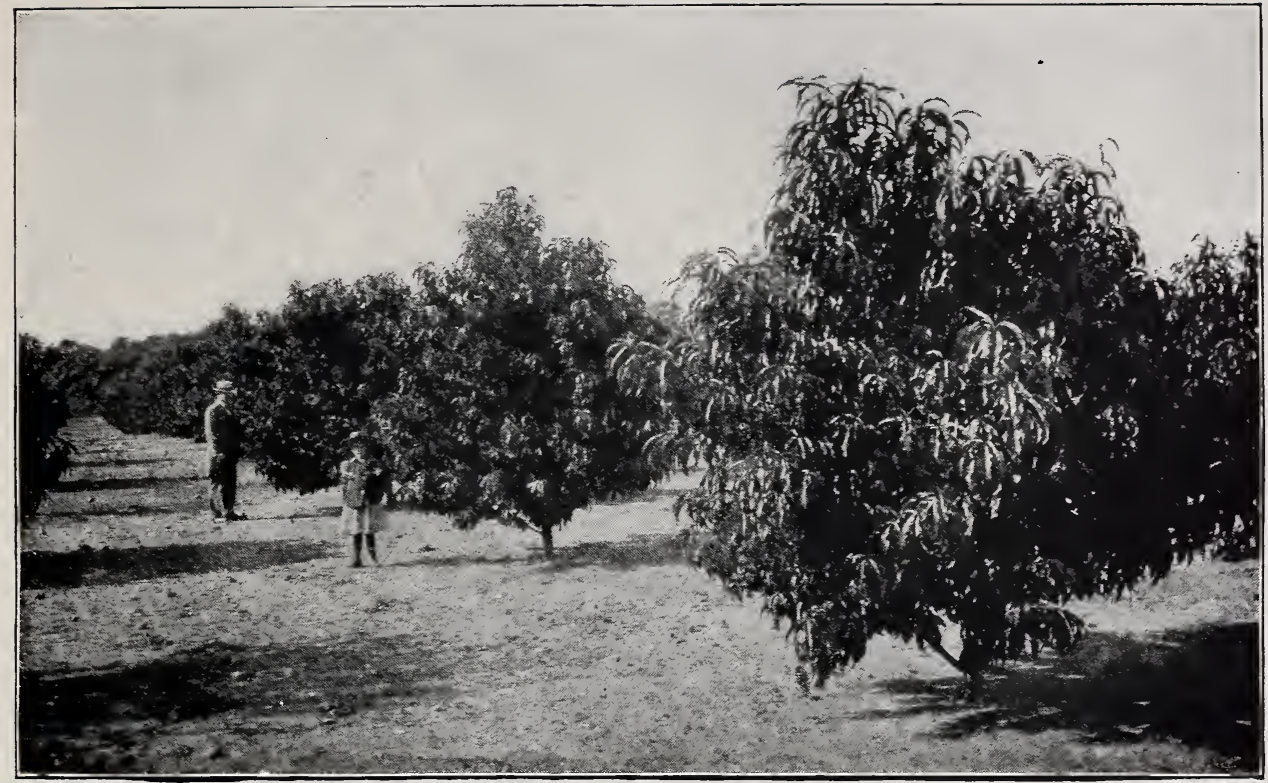

Individual Trees in C. W. Ward's Peach Orcharḋ (See, also, 2d cover page)

\section{ORCHARDS PLANTED WITH OUR TREES}

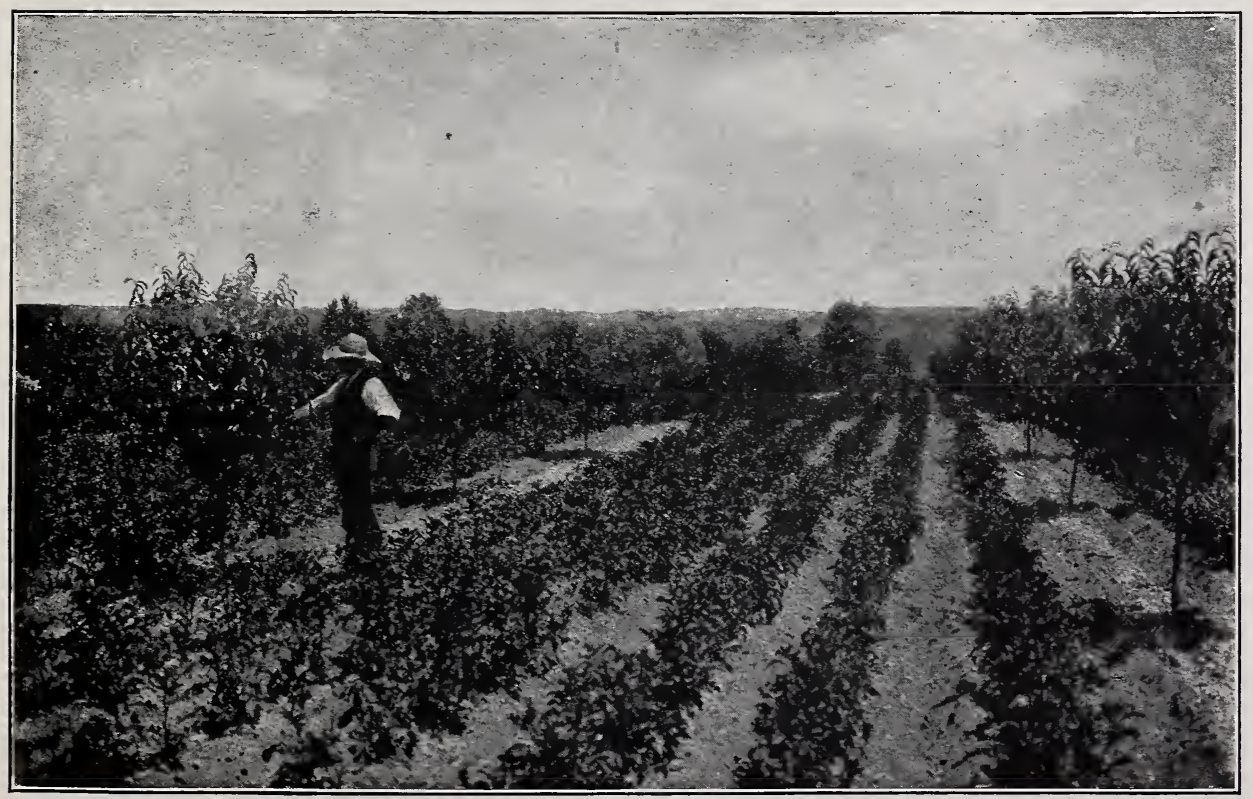

Orchard of Mr. John M. Snowden, Bowie, Prince George County, Maryland

J. Horace McFarland Co., Horticultural Printers, harrisburg, Pa. 


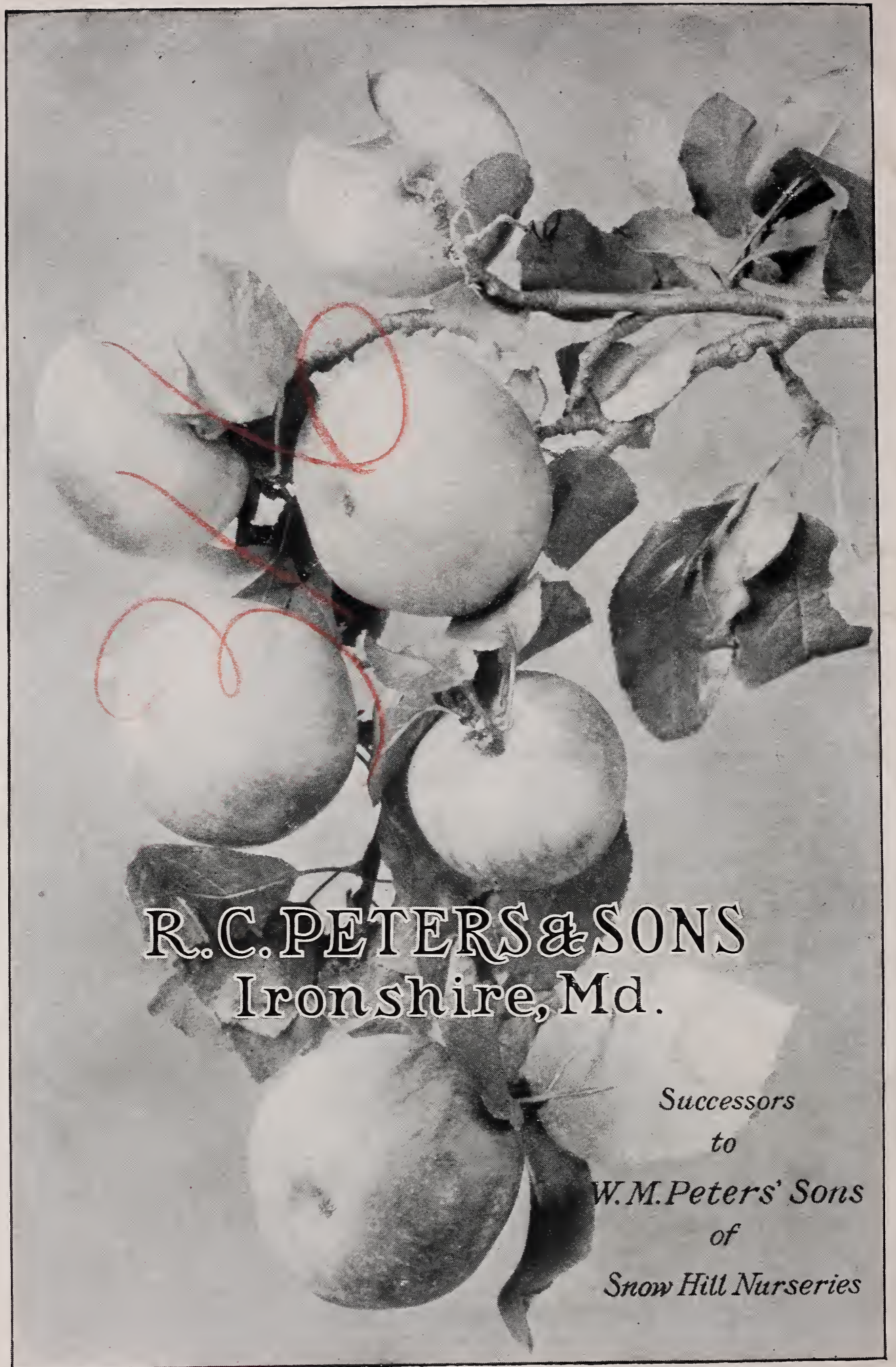

